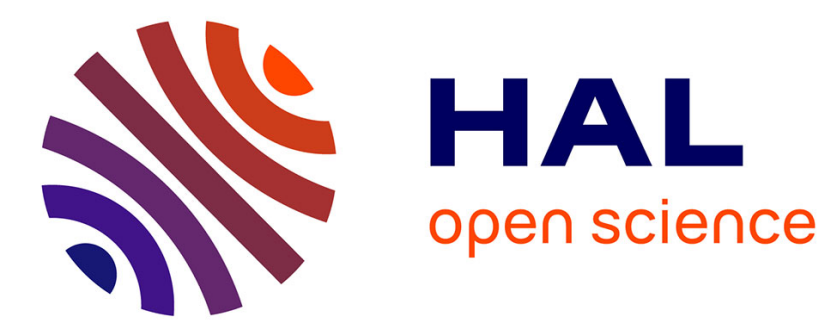

\title{
Predicting diurnal variability of fine inorganic aerosols and their gas-phase precursors near downtown Mexico City
}

\author{
M. Moya, C. Fountoukis, A. Nenes, E. Matías, M. Grutter
}

\section{- To cite this version:}

M. Moya, C. Fountoukis, A. Nenes, E. Matías, M. Grutter. Predicting diurnal variability of fine inorganic aerosols and their gas-phase precursors near downtown Mexico City. Atmospheric Chemistry and Physics Discussions, 2007, 7 (4), pp.11257-11294. hal-00303023

\section{HAL Id: hal-00303023 \\ https://hal.science/hal-00303023}

Submitted on 2 Aug 2007

HAL is a multi-disciplinary open access archive for the deposit and dissemination of scientific research documents, whether they are published or not. The documents may come from teaching and research institutions in France or abroad, or from public or private research centers.
L'archive ouverte pluridisciplinaire HAL, est destinée au dépôt et à la diffusion de documents scientifiques de niveau recherche, publiés ou non, émanant des établissements d'enseignement et de recherche français ou étrangers, des laboratoires publics ou privés. 


\section{Predicting diurnal variability of fine inorganic aerosols and their gas-phase precursors near downtown Mexico City}

M. Moya ${ }^{1}$, C. Fountoukis ${ }^{2}$, A. Nenes ${ }^{2,3}$, E. Matías ${ }^{4}$, and M. Grutter ${ }^{1}$

${ }^{1}$ Centro de Ciencias de la Atmósfera, Universidad Nacional Autónoma de México, Ciudad Universitaria, 04510, Mexico City, Mexico

${ }^{2}$ School of Chemical and Biomolecular Engineering, Georgia Institute of Technology, 311 Ferst Drive, Atlanta, GA 30332-0100, USA

${ }^{3}$ School of Earth and Atmospheric Sciences Georgia Institute of Technology, 311 Ferst Drive, Atlanta, GA 30332-0100, USA

${ }^{4}$ Posgrado en Ciencias Químicas, Universidad Nacional Autónoma de México, Ciudad Universitaria, 04510, Mexico City, Mexico

Received: 19 June 2007 - Accepted: 27 June 2007 - Published: 2 August 2007

Correspondence to: M. Moya (mmoya@servidor.unam.mx)

\section{ACPD}

Thermodynamic partitioning of inorganics in downtown Mexico

M. Moya et al.

Title Page
Abstract

Tables

14

4

Back
Conclusions
Introduction

References

Figures

$\rightarrow$

Close
Full Screen / Esc

Printer-friendly Version

Interactive Discussion 


\section{Abstract}

Partitioning of semi-volatile nitrate and ammonium between the gas and particulate phases is studied combining two thermodynamic models that explicitly include crustal elements and simulate both branches (deliquescence, efflorescence) of aerosol be-

5 havior and measurements taken near downtown Mexico City during a field campaign conducted in February-March, 2005. Overall, no significant differences between model predictions (within $30 \%$ of error) are observed for particulate ammonium $\left(\mathrm{PM}_{2.5}, \mathrm{PM}_{1}\right)$. In cases of moderate to high $\mathrm{RH}(40-70 \%)$, mostly occurring during the 1 st and 2nd daily sampling periods (06:00-10:00 h, 10:00-14:00 h, LST), $4 \mathrm{~h} \mathrm{PM}_{2.5}$ nitrate measurements are predicted within $30 \%$. When $\mathrm{RH}$ drops below $30 \%$, characteristic of the afternoon sampling periods (14:00-18:00 h), the efflorescence branch is most consistent with observed PM nitrate. Residual error analysis of these low $\mathrm{RH}$ cases suggest that aerosol nitrate loading or sulfate-to-nitrate molar ratio control phase behavior, hence the partitioning of semi-volatile $\mathrm{PM}_{2.5}$ nitrate in gas and particulate phases. Fi15 nally, inclusion of crustal elements in the modeling framework reduces the error in predicted $\mathrm{PM}_{2.5}$ ammonium by $25 \%$. These findings, if generally applicable, can help improve air quality modeling in nitrate deficient environments.

\section{Introduction}

Atmospheric aerosols reduce visibility, affect climate and air quality, and adversely impact human health. It is now recognized that smaller sizes $\left(\mathrm{PM}_{2.5}, \mathrm{PM}_{1}\right)$ of atmospheric particles as penetrating deeper into the lung exacerbate chronic respiratory and pulmonary diseases (Nikasinovich et al., 2006). A strong link has also been established between high aerosol concentrations and cardiovascular effects (Peters, 2005; Schulz et al., 2005; Englert, 2004). Particulate air pollution has also been associated with neurodegenerative effects and premature death (Peters et al., 2006).

The ability to simulate the aerosol size distribution and composition is key for deter-
Thermodynamic partitioning of inorganics in downtown Mexico

M. Moya et al.

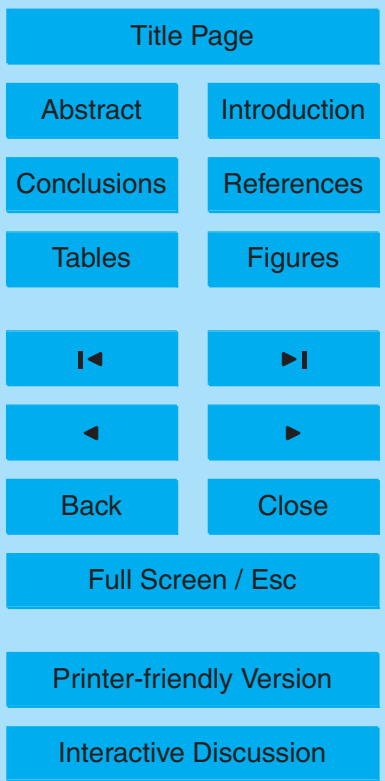


mining its role in atmospheric processes and impacts on public health. This is a challenging problem, as particulate matter is a complex mixture of chemical constituents that evolve rapidly over space and time. Airborne PM is composed of inorganic salts, organic material, crustal elements and trace metals (Seinfeld and Pandis, 1998). In-

5 organics may account for $50 \%$ or more of total fine particulate matter, a significant fraction of which can be salts of ammonium with sulfate, nitrate and chloride. Crustal species from mineral dust, such as $\mathrm{Ca}, \mathrm{K}$, and $\mathrm{Mg}$, are often present in large quantities in the coarse fraction of PM (particles with diameter larger than $2.5 \mu \mathrm{m}$ ) as dust (Ansari and Pandis, 1999a). Measurements of the chemical composition of aerosols and their 10 gas-phase precursors (especially in polluted areas) are essential for understanding the partitioning of semivolatile species (such as ammonia and nitrate) between the gas and particulate phases and to validate aerosol models.

The high levels of ozone $\left(\mathrm{O}_{3}\right)$ and aerosols (particulate matter, $\mathrm{PM}$ ) in the Mexico City Basin (MC) has become a significant issue for its nearly 20 million of inhabitants 15 (Molina and Molina, 2002). $\mathrm{PM}_{10}$ levels (PM with diameter less than $10 \mu \mathrm{m}$ ) exceed the 24-h standard almost every day of the year (Edgerton et al., 1999). $\mathrm{PM}_{2.5}$ levels have been recorded above the recently introduced standard of $65 \mu \mathrm{g} \mathrm{m}^{-3}$ as well (Moya and Huey, 2007). The scarcity of information about Mexico City aerosols, particularly in the fine fraction $\left(\mathrm{PM}_{1}, \mathrm{PM}_{2.5}\right)$ and their gas-phase precursors, has motivated a num20 ber of field campaigns. The first was IMADA-AVER (Edgerton et al., 1999), in which a complete dataset of $\mathrm{PM}_{2.5}$ constituents and their gas-phase precursors were obtained at a site near downtown Mexico City (Merced, MER) and evaluated with four thermodynamic equilibrium models by Moya et al. (2001). An important issue that came out of the analysis was the effect of long integration time (6-h) of the PM and gas-phase 25 measurements; the large $\mathrm{T}$ and $\mathrm{RH}$ variability over the sampling period ( $\mathrm{T}$ 's: $10-27^{\circ} \mathrm{C}$; RH's: $20-70 \%$ ) was a major source of uncertainty in comparing the observations with predictions.

Since IMADA-AVER, measurements in and around the metropolitan area of MC were carried out during the months of February and/or March of 2003 and 2005 at

Thermodynamic partitioning of inorganics in downtown Mexico

M. Moya et al.

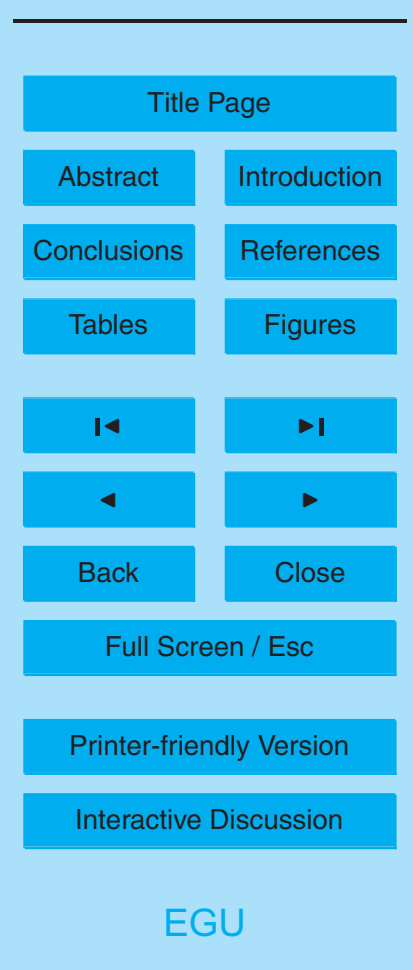


the Merced (MER) site downtown Mexico City (MER 2003 and MER 2005, respectively), as well as other international initiatives during 2003 and 2006 (MCMA-2003, and MILAGRO, respectively). Among the objectives pursued in these investigations are (1) chemically characterize the fine fraction of aerosols along with the gas-phase 5 precursors in this megacity (e.g. Moya et al., 2004; Moya and Huey, 2007), and, (2) to evaluate the ability of bulk equilibrium models to describe semivolatile partitioning of inorganics, which is the focus of this study.

Predicting the equilibrium composition of the complex $\mathrm{MC}$ aerosol is a stringent test for aerosol thermodynamic models. In addition to the large degree of external mix10 ing, there are large amounts of crustal material present which has been shown to strongly affect partitioning of semi-volatile inorganics in this polluted area (e.g. Moya et al, 2002b). Another important aspect in aerosol modeling is to know the real phase state of atmospheric aerosol behavior as they can follow either the deliquescence branch (in which solids precipitate) or the efflorescence branch (in which solids are not allowed to precipitate and the particle is an aqueous phase solution). Depending on the $\mathrm{RH}$ history, solids or aqueous phase may be present in the system. As $\mathrm{RH}$ increases the deliquescence behavior, occurring naturally, is characteristic of aerosol behavior. As $\mathrm{RH}$ decreases, the particle may follow a different path in which does not crystallize at its initial deliquescence point but instead holds water until a much lower $\mathrm{RH}$ forming a supersaturated solution. Ansari and Pandis (2000) highlighted the importance of considering both branches of aerosol behavior, particularly when nitrate concentrations were low $\left(<8 \mu \mathrm{g} \mathrm{m}^{-3}\right)$. For high $\left(>8 \mu \mathrm{g} \mathrm{m}^{-3}\right)$ nitrate PM loading no significant difference between efflorescence and deliquescence branches was observed for Southern California ambient conditions. For the same area, Moya et al. (2002a) 25 illustrated that the assumption of metastable state when $\mathrm{RH}<60 \%$ might introduce unacceptable errors in predicting aerosol behavior. In this context, diurnal variability of ambient parameters (Temperature: $10-27^{\circ} \mathrm{C} ; \mathrm{RH}: 20-70 \%$ ) measured at downtown MC during the 2005 winter-dry season as well as other aspects of chemical composition (e.g. low-to-moderate nitrate particle loading) of heterogeneous aerosols in this

Thermodynamic partitioning of inorganics in downtown Mexico

M. Moya et al.

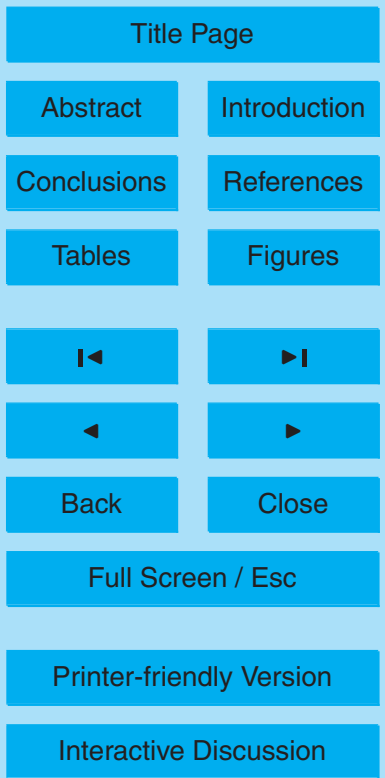


area represent a singular case of study to evaluate the ability of bulk thermodynamic equilibrium models in representing inorganic aerosol behavior.

In the present work, using 4-h average aerosol and inorganic gas phase precursors $\left(\mathrm{NH}_{3}, \mathrm{HNO}_{3}\right)$ measured during the MER 2005 study, and by applying two thermody5 namic models: SCAPE2 (Kim et al., 1993a, b; Kim and Seinfeld, 1995; Meng et al., 1995) and ISORROPIA-II (Fountoukis and Nenes, 2007), we attempt to evaluate the ability of thermodynamic models to capture the observed partitioning of semi-volatile inorganics. Both thermodynamic models were chosen as they explicitly include crustal species, which has been shown to be important for understanding the partitioning be-

10 havior. The aforementioned models are able to simulate both branches (deliquescence and efflorescence) of inorganic aerosol behavior and water uptake of aerosol, a relevant aspect in defining the real phase state of $\mathrm{MC}$ aerosol.

\section{Field campaign}

\subsection{Sampling site description}

15 During the 2005 MER study, measurements were carried out at a site near downtown Mexico City (the MER: $19.38^{\circ} \mathrm{N}, 99.12^{\circ} \mathrm{W}$ ) from 7 February to 4 March 2005. A detailed description of the site is given by Moya et al. (2004). Briefly, MER is a characteristic urban-site surrounded by near heavily traveled paved streets with light-duty vehicles and heavy-duty diesel buses (Edgerton et al., 1999) located in an area with $\sim 14000$ inhabitants per $\mathrm{km}^{2}$ (INEGI, 2000). The Mexico City International Airport is $\sim 3 \mathrm{~km}$ to the east and the dry-salt lake of Texcoco covering an area of $\sim 12 \mathrm{~km}^{2}$ and located 15 $\mathrm{km}$ NE from the MER site, has been suggested in previous studies as an important source of sodium and crustal species.

Thermodynamic partitioning of inorganics in downtown Mexico

M. Moya et al.

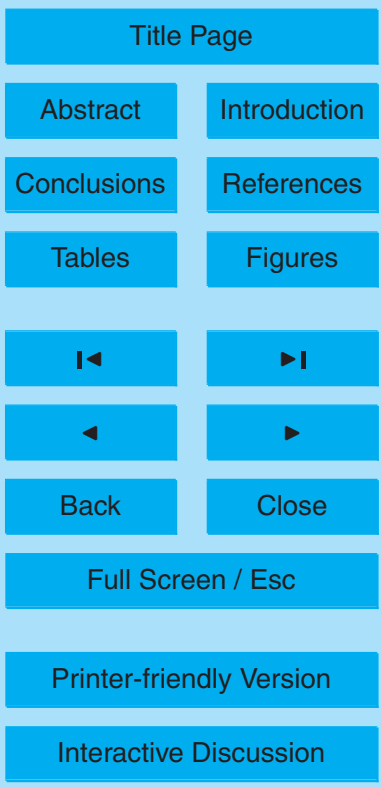


The Valley of Mexico elevation is $2240 \mathrm{~m}$ above mean sea level. In spite of its altitude, latitude of $19^{\circ} \mathrm{N}$ ensures a temperate climate throughout the year. Over the winter-dry period, when the study was conducted, the temperature and relative humidity averaged $518^{\circ} \mathrm{C}$ and $42 \%$, respectively. Figure 1 shows the average diurnal pattern of these parameters, measured at the MER site (operated by the RAMA, Gobierno del Distrito Federal, Mexico City) throughout the period of study. The ranges of temperature ( $T$ ) and relative humidity $(\mathrm{RH})$ registered during the sampling periods of study were as follows: $10-14^{\circ} \mathrm{C}$ and $39-72 \%(06: 00-10: 00 \mathrm{~h} \mathrm{LST}), 17-22^{\circ} \mathrm{C}$ and $29-47 \%(10: 00-$ $1014: 00 \mathrm{~h} \mathrm{LST})$, and $23-26^{\circ} \mathrm{C}$ and $23-35 \%(14: 00-18: 00 \mathrm{~h}$ LST). This variability will be one of the key issues to be analyzed when model simulations are discussed.

\subsection{Particulate matter measurements}

Bulk $\mathrm{PM}_{1}, \mathrm{PM}_{2.5}$ and size-differentiated $\mathrm{PM}_{10}(0.18-10 \mu \mathrm{m}, 50 \%$ cutoff aerodynamic diameter) were measured from 7 February through 4 March 2005 over the aforemen15 tioned sampling periods: 1st: 06:00-10:00 h LST, 2nd: 10:00-14:00 h LST, and 3rd: 14:00-18:00 h LST. Inorganic particulate species measured include sulfate, nitrate, chloride, ammonium, sodium, potassium, calcium and magnesium. The procedure for collection of size-resolved inorganics in MER 2005 field study was identical to the MER 2003 field campaign (described in Moya et al., 2004). All measurements were 20 performed at ambient temperature and $\mathrm{RH}$. Bulk $\mathrm{PM}_{1}$ and $\mathrm{PM}_{2.5}$ measurements were filter-based (using URG systems and Teflon/Nylon substrates). Details of the collection of bulk chemical species are presented by Matías (2007). Based on physical and chemical consistency tests (data validation) between our $\mathrm{PM}_{10}$ size-resolved and "bulk" $\mathrm{PM}_{2.5}$ systems versus $\mathrm{PM}_{10}, \mathrm{PM}_{2.5}$ EPA referenced systems from the RAMA-MER site, 25 validated data corresponded to our bulk PM systems and these measurements were used for modeling purposes at the present work. Filter-based $\mathrm{PM}_{2.5}$ and $\mathrm{PM}_{1}$ nitrate considered only the non-volatilized part. A full description of the analytical methods

Thermodynamic partitioning of inorganics in downtown Mexico

M. Moya et al.

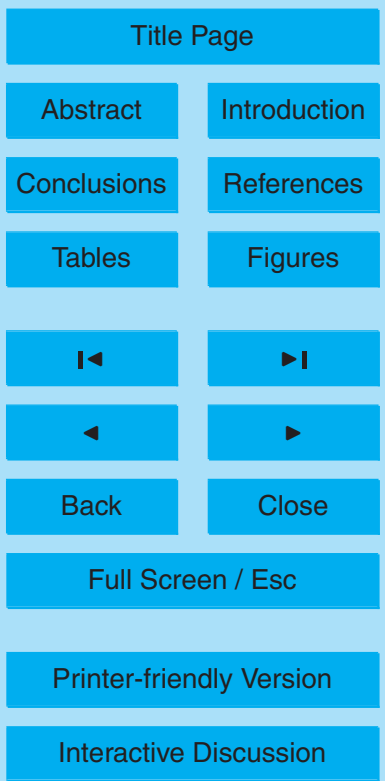


employed for the chemical analyses of the inorganic fraction of particles using highperformance liquid chromatography and atomic absorption spectrometry is presented by Moya et al. (2004).

\subsection{Gas-phase measurements}

5 Real-time gas-phase $\left(\mathrm{NH}_{3}, \mathrm{HNO}_{3}\right)$ was measured with an open-path FTIR spectrometer. Briefly, an infrared beam is sent $426 \mathrm{~m}$ across the atmosphere using a bistatic

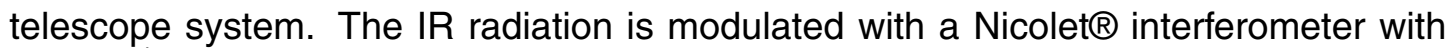
$0.5 \mathrm{~cm}^{-1}$ resolution and captured with a $\mathrm{HgCdTe}$ detector at $77 \mathrm{~K}$. The concentrations are retrieved from the 5 min co-added interferograms by performing a non-linear CLS regression using a synthetic background and references generated from the HITRAN spectroscopic database (Rothman et al., 1998). Details of the experiment are presented elsewhere (Grutter et al., 2003). For the quantitative analysis of $\mathrm{NH}_{3}$ and $\mathrm{HNO}_{3}$, the spectral bands of $920-1090 \mathrm{~cm}^{-1}$ and $875-900 \mathrm{~cm}^{-1}$ are used, respectively. Diurnal pattern of gas-phase $\mathrm{NH}_{3}$ is shown in Fig. 2; very high mixing ratios of ammonia

15 were observed up to $62 \mathrm{ppb}$, average 1-h peak values around $33 \mathrm{ppb}$, mostly occurred during the early morning sampling periods (08:00 a.m.). Overall, these high values and the diurnal profile observed for gas-phase $\mathrm{NH}_{3}$ during 2005 are very similar in trends to those first observed in downtown Mexico City in 2003 (Moya et al., 2004).

The uncertainty in measured nitric acid is large ( $40 \%)$ due to its small absorption cross-section in the infrared. Moya et al. (2004) suggested to determine gas-phase $\mathrm{HNO}_{3}$ by another analytical technique. This was performed by the denuder difference method (DDM, Shaw et al., 1982; Chow et al., 1993) to further constrain the uncertainty associated with the $\mathrm{HNO}_{3}$ measurement. Measurements were performed (Fig. 3) in diurnal four-hour sampling periods in accord with the collection of airborne fine particulate matter at the MER site. An analysis of $\mathrm{HNO}_{3}$ levels measured at the MER 2005 study versus those recorded during the IMADA-AVER campaign (Edgerton et al., 1999) was performed and suggested nitric acid measurements from the denuder system $\left(\mathrm{DDM}^{-} \mathrm{HNO}_{3}\right)$ were more reliable to be used in thermodynamic calculations than

Thermodynamic partitioning of inorganics in downtown Mexico

M. Moya et al.

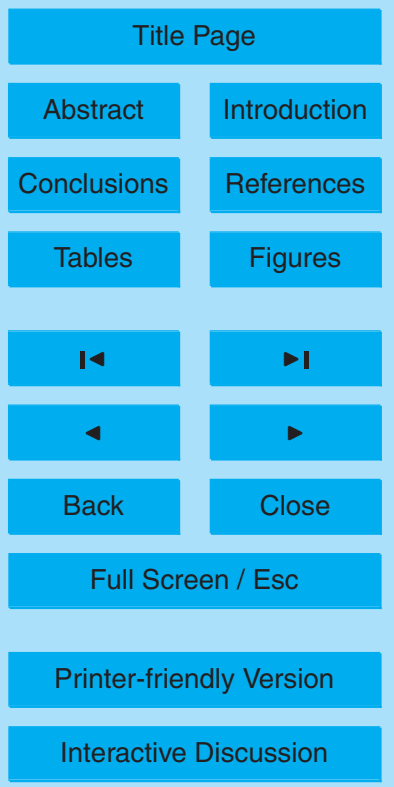


those from the FTIR system (FTIR- $\mathrm{HNO}_{3}$ ).

Figure 4 shows gas-particle diurnal behavior and Tables 1 and 2 show the average and maximum values of $4 \mathrm{~h} \mathrm{PM}_{1}, \mathrm{PM}_{2.5}$ measurements as well as gas- and particle-phase mass fractions (where applicable) for total (sum of gas and particulate 5 phase) ammonium, nitrate, sulfate and crustal species. Ammonium and nitrate occurred mainly during the 2nd (10:00-14:00 h) once the precursors have been emitted during the first hours in the early morning (06:00-10:00 h). Ammonia remained mainly in the gas phase (around $60 \%$ of diurnal average, $75 \%$ in the early morning period), while $\mathrm{PM}_{2.5}$ nitrate remained in the particulate phase (around $70 \%$ diurnal average). 10 The same pattern is seen in the $\mathrm{PM}_{1}$ fraction as well (not shown).

\section{Modeling aerosol thermodynamic equilibrium}

Several atmospheric models based on thermodynamic equilibrium have been developed to predict the partitioning of inorganic species between the gas and particulate phases, as SEQUILIB (Pilinis and Seinfeld, 1987), AIM2 (Wexler and Seinfeld, 15 1991; Clegg et al., 1992, 1994, 1995, 1998a, b, 2003; Wexler and Clegg, 2002), SCAPE2 (Kim and Seinfeld, 1995; Meng et al., 1995), EQUISOLV-II (Jacobson et al., 1996; Jacobson 1999), GFEMN (Ansari and Pandis, 1999a), EQSAM (Metzger et al., 2002; Trebs et al., 2005), MESA (Zaveri et al., 2005), ADDEM (Topping et al., 2005), ISORROPIA-II (Fountoukis and Nenes, 2007), UHAERO (Amundson et al., 2006). These models require knowledge of total ammonium, nitrate, sulfate, chloride and, in some cases, crustal species such as $\mathrm{Ca}^{2+}, \mathrm{K}^{+}, \mathrm{Mg}^{2+}$ to predict the concentration of the species in the gas and aerosol phases, and within the aerosol phase, between the solid and aqueous phases.

SCAPE2 and ISORROPIA II were chosen for this study as models that can comprehensively treat crustals and can predict for both deliquescence and efflorescence paths of aerosol behavior. "Deliquescence path" is when solids are allowed to precipitate out of solution upon saturation; under this assumption, single-component aerosol

Thermodynamic partitioning of inorganics in downtown Mexico

M. Moya et al.

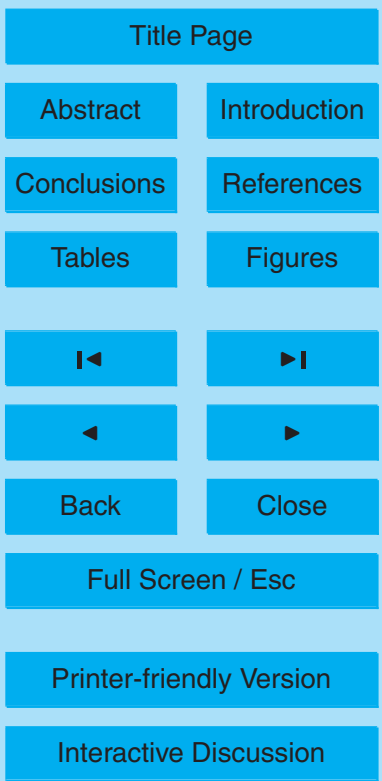


transitions to a saturated aqueous solution at a characteristic "relative humidity of deliquescence" (which is when the ambient relative humidity is equal to the water activity of the saturated solution). The "metastable path" is when solids do not precipitate out of the solution regardless of its saturation state. In agreement with Ansari and

5 Pandis (2000), Moya et al. (2002a, b) found that for conditions typical of dry-winter Mexico City, both branches may be required when predicting aerosol behavior. Both SCAPE2 and ISORROPIA II treat the equilibrium problem by solving a set of nonlinear algebraic equations (reaction equations) simultaneously with electroneutrality and mass conservation equations for each species. ISORROPIA-II explicitly treats the mu10 tual deliquescence region (MDRH, Wexler and Seinfeld, 1991, Nenes et al., 1998) for which the multicomponent salts are saturated with respect to their aqueous phase solution. In both models, Kussik-Meissner (Kussik and Meissner, 1978) binary and the Bromley (Bromley, 1973) multicomponent activity coefficient methods are used. The two models differ in the deliquescence behavior, as ISORROPIA II uses the concept of 15 "compositional invariance with RH cycling" (Fountoukis and Nenes, 2007).

\section{Results and discussion}

\subsection{Attributes of simulations}

The ensuing analysis focuses on the behavior of $\mathrm{PM}_{1}, \mathrm{PM}_{2.5}$ in Mexico City. Henceforth, fine particulate concentrations refer either to particles with aerodynamic diameters $\leq 2.5$ micrometers $\left(\mathrm{PM}_{2.5}\right)$ or $\leq 1$ micrometer $\left(\mathrm{PM}_{1}\right)$. Overall, $39\left(\mathrm{PM}_{1}, \mathrm{PM}_{2.5}\right)$ cases corresponding to the winter sampling period of 17 through 23 February, and 4 March 2005 at the MER site were analyzed. Each data point corresponds to $4 \mathrm{~h}$ averaged measurements of aerosol components and gas-phase precursors $\left(\mathrm{NH}_{3}-\mathrm{FTIR}\right.$, $\mathrm{HNO}_{3}$-DDM) which are then summed up to calculate the total concentrations of nitrate 25 and ammonia.

Calculation of activity of aqueous species in SCAPE2 and ISORROPIA-II is per-

Thermodynamic partitioning of inorganics in downtown Mexico

M. Moya et al.

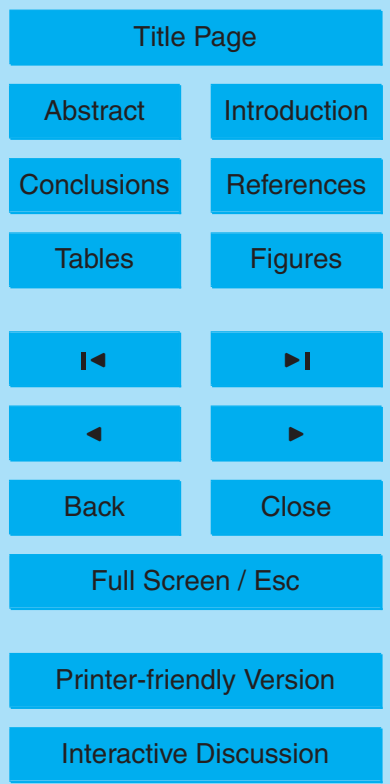


formed using Kussik-Meissner and Bromley's binary and multicomponent activity coefficients methods. For consistency, both models share the same water activity database, which was obtained from the AIM model (http://www.hplc.uea.ac.uk/ e770/aim.html) and recent water activity data from $\mathrm{Ha}$ and Chan (1999) and Kelly and Wexler (2006).

Following proposed formulas of Lurmann et al. (1997), the prediction skill of each model was quantified in terms of the mean normalized error (MNE), MNE $=\frac{\sum_{i}^{n}\left|P_{i}-O_{i}\right|}{\sum_{i}^{n} O_{i}}$, and mean normalized bias (MNB), MNB $=\frac{\sum_{i}^{n}\left(P_{i}-O_{i}\right)}{\sum_{i}^{n} O_{i}}$, where $P_{i}$ and $O_{i}$ represent predictions and observations of data point $i$, respectively, and $n$ is the total number of data points. MNE is related to the overall discrepancy between predictions and observations, while MNB gives information on systematic errors.

\subsection{Aerosol phase transitions: stable or metastable?}

Tables 3-6 show statistics of SCAPE2 and ISORROPIA-II performance considering deliquescence (stable) branch. Tables 7-10 show same analysis considering the efflorescence (metastable) path of aerosol behavior. Overall, no significant differences between model predictions were observed by applying any of the branches for cases where $\mathrm{RH}>40 \%$ (1st and 2nd sampling periods). For these cases, particulate $\left(\mathrm{PM}_{1}\right.$, $\mathrm{PM}_{2.5}$ ) ammonium and $\mathrm{PM}_{2.5}$ nitrate is predicted within $20-40 \%$ of error while $\mathrm{PM}_{1}$ nitrate is not adequately predicted for the 1st sampling periods (MNE around 60\%). For low $\mathrm{RH}$ values (afternoon sampling periods), by applying the efflorescence path, $\mathrm{PM}_{2.5}$ nitrate predictions significantly improves ( 20\% and $~ 50 \%$ for SCAPE2 and ISORROPIA II, respectively). Nevertheless, mean normalized errors for these low $\mathrm{RH}$ cases are still significant $(\sim 50 \%)$ as well as $\mathrm{PM}_{1}$ nitrate during the early morning sampling periods $(\sim 60 \%)$. For these particular cases, a further analysis is provided below.

Thermodynamic partitioning of inorganics in downtown Mexico

M. Moya et al.

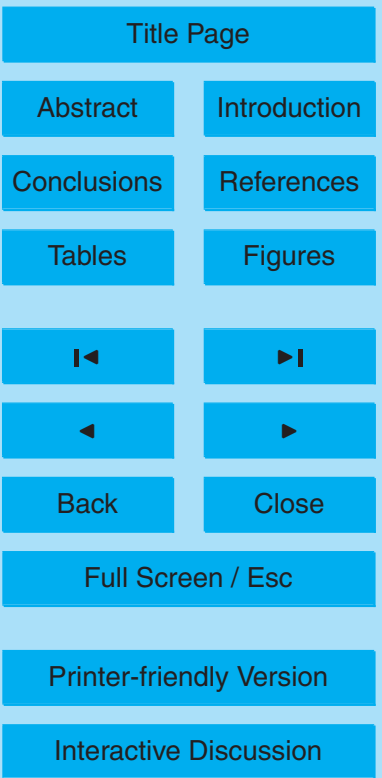


Ansari and Pandis (2000) stressed the importance of considering metastable equilibrium states in thermodynamic modeling. Based on this, Moya et al. (2001) postulated that assuming a metastable aerosol for winter-dry ambient conditions would improve Mexico City $\mathrm{PM}_{2.5}$ nitrate predictions; the validity of this postulation is assessed. By 5 applying the efflorescence branch of the equilibrium approach for low $\mathrm{RH}$, Table 11 presents the concentration range of particulate nitrate $\left(\mathrm{PM}_{1}, \mathrm{PM}_{2.5}\right)$ measurements, stratified by sampling period. For low $\mathrm{RH}$ cases (3rd sampling periods) where greater differences between both branches were observed, low aerosol nitrate concentrations $\left(<3 \mu \mathrm{g} \mathrm{m}^{-3}\right)$ were recorded at the MER site. Also, $\mathrm{PM}_{1}$ nitrate concentration during the 10 early morning sampling periods was relatively low $\left(<8 \mu \mathrm{g} \mathrm{m}^{-3}\right)$. Extending our analysis by calculating sulfate-to-nitrate molar ratios on these low nitrate loading cases (see Table 12) it is seen that when the ratio is greater than 1, predicted particulate nitrate significantly improves if the aerosol follows the efflorescence path. Furthermore, Fountoukis et al. (2007) have shown that when the sulfate-to-nitrate molar ratio is less 15 than 1, predictions improve substantially if the aerosol follows the deliquescent path. Together, both analyses suggest that aerosol nitrate loading and sulfate-to-nitrate molar ratio profoundly impacts the phase behavior at low $\mathrm{RH}$, hence the partitioning of semi-volatile $\mathrm{PM}_{2.5}$ nitrate in gas and particulate phases.

\subsection{Importance of including crustal species}

20 It has been known that crustal and dust-related chemical species can play an important role in the partitioning of semi-volatile inorganics (e.g. Seinfeld and Pandis, 1998; Lee et al., 2003; Kline et al., 2004; Maxwell-Meier et al., 2004). We examine the role of crustals by applying ISORROPIA-II (efflorescence branch) on the current dataset. Tables 9-10 and 13-14 show results for $\mathrm{PM}_{1}, \mathrm{PM}_{2.5}$ model simulations, including (Tables 9-10) and no including (Tables 13-14) crustal species. Table 15 presents concentration of anions and cations stratified by sampling period for the system under study. As seen in Tables 9-10 and 13-14, no significant improvement is observed for $\mathrm{PM}_{1}$, $\mathrm{PM}_{2.5}$ nitrate considering crustals in simulations. However, for ammonium $\mathrm{PM}_{2.5}$ an

Thermodynamic partitioning of inorganics in downtown Mexico

M. Moya et al.

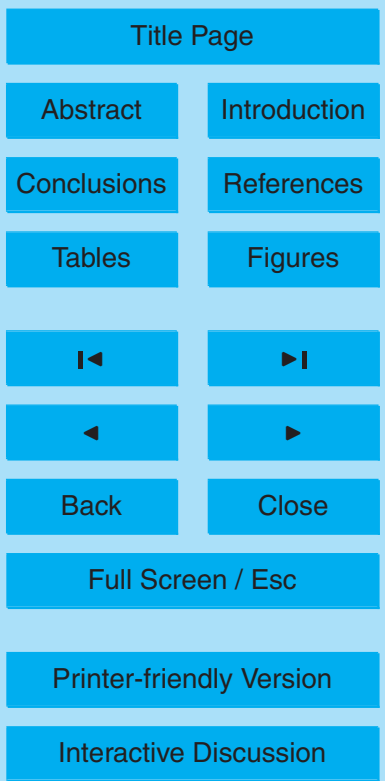


improvement of $25 \%$ in MNE is observed for 1 st sampling periods when considering crustals in simulations. As seen in Table 15, the presence of crustals (particularly $\mathrm{Ca}^{2+}$ ) in this case is substantial with regards to the other sampling periods ( $2 n d$ and $3 \mathrm{rd}$ ). The sulfate and crustals-rich environment of the 1st sampling period cases $\left(\mathrm{PM}_{2.5}\right)$ allows 5 the preferred formation of $\mathrm{CaSO}_{4}$ in the system, which is translated to an improvement in predicted $\mathrm{PM}_{2.5}$ ammonium. For $\mathrm{PM}_{1}$, where overall concentration of crustals is significantly less, this improvement in predicted ammonium is not observed. On the other hand, during the 3rd sampling periods, when the system is not enough in concentration of anions (Table 15) to fully neutralize the cations (ammonium and crustals), the 10 effect of adding crustals to the system may be complex and counterintuitive. However, the study of these afternoon sampling period cases deserves further investigation, as nitrate volatilization of the system may be occurring (see Sect. 4.4).

\subsection{Other important issues}

Whether or not bulk aerosol approach is a good approximation of aerosol composi15 tion and partitioning has been extensively discussed in the literature (Jacobson, 1999; Wexler and Seinfeld, 1990, 1992; Ansari and Pandis, 1999b) our measurements based on bulk filter sampling which can mix acidic with alkaline particles, address this issue quite effectively; error in predicted partitioning in part reflects this mixing across particle sizes. The extent of "bulk" vs. "size-resolved" partitioning on prediction error cannot be 20 fully assessed, as our measurement contains no information regarding the change in alkalinity/acidity of particles with size. However, the error is likely accounts for approximately $10 \%$ or so of the overall MNE. Results discussed in the present work show that the equilibrium assumption, when applied to timescales of $4 \mathrm{~h}$, gives a prediction error of $\sim 30 \%$ MNE for particulate ammonium and $\sim 30-50 \%$ MNE for particulate nitrate 25 (when considering all ranges, i.e., low-high ranges of aerosol nitrate loading).

Another issue is the effect of long sampling times, as discussed in previous modeling work under Mexico City conditions (Moya et al., 2001). In spite of the reduction of PM sampling periods $(4 \mathrm{~h})$ in the MER 2005 study versus previous ones (e.g. $6 \mathrm{~h}$, IMADA-

Thermodynamic partitioning of inorganics in downtown Mexico

M. Moya et al.

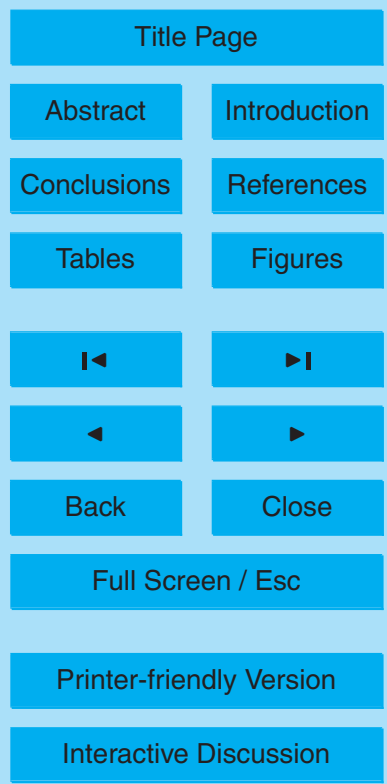

EGU 
AVER field study; Edgerton et al., 1999), results presented here suggest that under periods of high variability of $\mathrm{T}$ and $\mathrm{RH}$ (Fig. 1), a faster time resolution in measurements is required for thermodynamic analysis.

Finally, the methods used in collecting samples during the field study (Moya and 5 Huey, 2007) are subject to experimental uncertainty because of the semivolatile nature of some inorganic compounds. Previous work (e.g. Schaap et al., 2004; Chang et al., 2000; Hearing and Cass, 1999; Chow et al., 1994) has reported significant losses of nitrate on filter-based aerosol samples. Uncertainties related to volatilized PM nitrate measurements deserves further analysis as they might introduce some errors in total 10 particulate nitrate concentrations considered for evaluate model performance.

\section{Conclusions}

This study analyzes the partitioning of nitrate and ammonium between the gas and particulate phases under dry-winter 2005 conditions of downtown Mexico City through application of thermodynamic models SCAPE2 and state-of-the-art ISORROPIA II. 15 Overall, no significant differences between model predictions (within $30 \%$ of error) are observed for particulate $\left(\mathrm{PM}_{1}, \mathrm{PM}_{2.5}\right)$ ammonium. $4 \mathrm{~h} \mathrm{PM}_{2.5}$ nitrate measurements are predicted in the same range of error for cases of moderate to high $\mathrm{RH}(40-70 \%)$. At low $\mathrm{RH}(<30 \%)$ characteristic of afternoon sampling periods (14:00-18:00 h), the metastable branch of the equilibrium assumption improves significantly (by $50 \%$ of

$20 \mathrm{MNE}$, ISORROPIA II simulations) predicted $\mathrm{PM}_{2.5}$ nitrate. Further analysis of sulfate-to nitrate molar ratios $(>1)$ on these low $\mathrm{RH}$ cases are in agreement with suggested findings by Ansari and Pandis (2000) regarding consideration of both branches of aerosol behavior. This study suggests that knowledge of the real state of the aerosol is of relevance for adequately modeling partitioning of semivolatile species between the gas and particulate phases, under Mexico City conditions. Finally, the inclusion of crustals improves predicted $\mathrm{PM}_{2.5}$, particularly ammonium, due to the sulfate-calcium rich environment (such as downtown Mexico City). These findings, if applicable to conditions

Thermodynamic partitioning of inorganics in downtown Mexico

M. Moya et al.

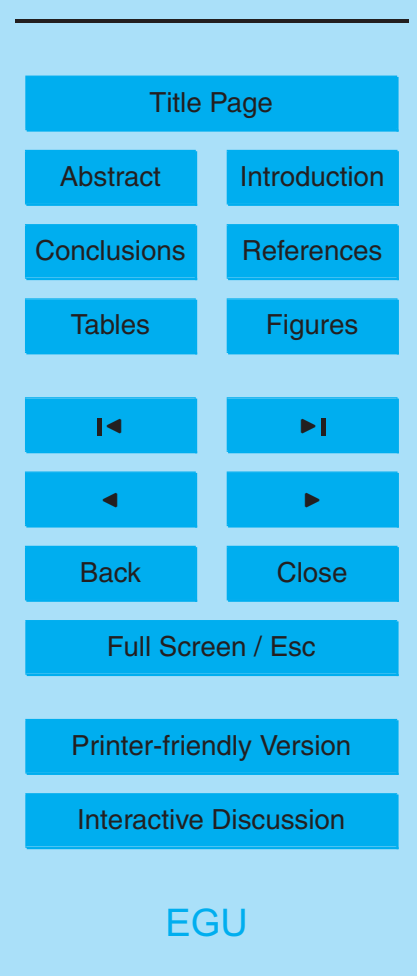


other than those found in Mexico City, can be a significant improvement in air quality modeling in nitrate deficient environments.

Acknowledgements. M. Moya acknowledges support from CONACyT-Ciencia Básica (J51782) and PAPIIT-UNAM (IN107306). A. Nenes and C. Fountoukis acknowledge support from NSF

5 CAREER, NOAA (NMRAC000-5-04017) and EPA (X83234201). Special acknowledgement to R. Ramos and A. Retama from the RAMA-GDF, E. Coz (CIEMAT-Spain), R. Basaldud, M. Murillo and E. Matias (UNAM) for technical support during the field campaign at the MER site (2003-2005). D. Flores is acknowledged for computing assistance.

\section{References}

Amundson, N. R., Caboussat, A., He, J. W., Martynenko, A. V., Savarin, V. B., Seinfeld, J. H., and Yoo, K. Y.: A new inorganic atmospheric aerosol phase equilibrium model (UHAERO), Atmos. Chem. Phys., 6, 975-992, 2006, http://www.atmos-chem-phys.net/6/975/2006/.

Ansari, A. and Pandis, S.: Prediction of multicomponent inorganic atmospheric aerosol behavior, Atmos. Environ., 34, 157-168, 1999a.

Ansari, A. and Pandis, S.: An analysis of four models predicting the partitioning of semi-volatile inorganic aerosol components, Aerosol Sci. Technol., 31, 129-153, 1999b.

Ansari, A. S. and Pandis, S. N.: The effect of metastable equilibrium states on the partitioning of nitrate between the gas and aerosol phases, Atmos. Environ., 34, 157-168, 2000.

Bromley, L. A.: Thermodynamic properties of strong electrolytes in aqueous Solutions, AIChE Journal, 19, 313-320, 1973.

Chang, M. C., Sioutas, C., Kim, S., Gong, H., and Linn, W. S.: Reduction of nitrate losses from filter and impactor samplers by means of concentration enrichment, Atmos. Environ., 34, 85-98, 2000.

Chow, J. C., Watson, J. G., Bowen, J. L.: A sampling system for reactive species in the western US: Sampling and analysis of airborne pollutants, Winegar, E. D. and Keith, L. H. Editors, Ann Arbor, MI: Lewis Publishers, Pages: 209-228, 1993.

Chow, J. C., Fujita, E. M., Watson, J. G. Lu, Z., and Lawson, D. R.: Evaluation of filter-based aerosol measurements during the 1987 Southern California Air Quality Study, Environ. Monit. Assess., 30, 49-80, 1994

Thermodynamic partitioning of inorganics in downtown Mexico

M. Moya et al.

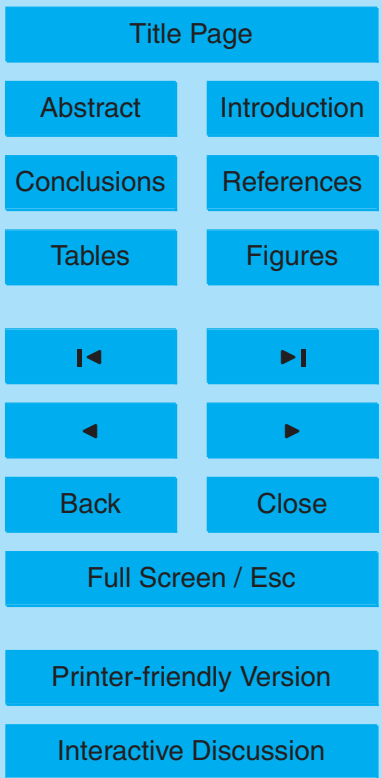


Chow, J. C.: Critical review: measurements methods to determine compliance with ambient air quality standards for suspended particles, J. Air Waste Manage., 45, 320-382, 1995.

Chow, J. C., Watson, J. G., Edgerton, S. A., and Vega, E.: Chemical composition of $\mathrm{PM}_{2.5}$ and $\mathrm{PM}_{10}$ in Mexico City during winter 1997, Sci. Total Environ., 287, 177-201, 2002.

5 Clegg, S. L., Pitzer, K. S., and Brimblecombe, P.: Thermodynamics of multicomponent, miscible, ionic solutions. Mixtures including unsymmetrical electrolytes, J. Phys. Chem. A., 96, 9470-9479, 1992.

Clegg, S. L. and Pitzer, K. S., Brimblecombe, P.: Thermodynamics of multicomponent, miscible, ionic solutions. Mixtures including unsymmetrical electrolytes, (additions and corrections for 10 their published papers), J. Phys. Chem., 98, 1368, 1994.

Clegg, S. L., Pitzer, K. S., and Brimblecombe, P.: Thermodynamics of multicomponent, miscible, ionic solutions. Mixtures including unsymmetrical electrolytes, (additions and corrections for their published papers), J. Phys. Chem. 99, 6755, 1995.

Clegg, S. L., Brimblecombe, P., and Wexler, A. S.: Thermodynamic Model of the System $15 \mathrm{H}^{+}-\mathrm{NH}_{4}^{+}-\mathrm{Na}^{+}-\mathrm{SO}_{4}^{2-}-\mathrm{NO}_{3}^{-}-\mathrm{Cl}^{-}-\mathrm{H}_{2} \mathrm{O}$ at Tropospheric Temperatures. J. Phys. Chem. A., 102, 2137-2154, 1998a.

Clegg, S. L., Brimblecombe, P., and Wexler, A. S.: Thermodynamic Model of the System $\mathrm{H}^{+}-\mathrm{NH}_{4}^{+}-\mathrm{Na}^{+}-\mathrm{SO}_{4}^{2-}-\mathrm{NO}_{3}^{-}-\mathrm{Cl}^{-}-\mathrm{H}_{2} \mathrm{O}$ at $298.15 \mathrm{~K}$, J. Phys. Chem. A., 102, 2155-2171, 1998b.

Clegg, S. L., Seinfeld, J. H., and Edney, E. O.: Thermodynamic modeling of aqueous aerosols containing electrolytes and dissolved organic compounds. II. An extended ZdanovskiiStokes-Robinson approach, J. Aerosol Sci., 34, 667-690, 2003.

Edgerton, S. A., Arriaga, J. L., Archuleta, J., Bian, X., Bossert, J. E., Chow, J. C., Coulter, R. L., Doran, J. C., Doskey, P. V., Elliot, S., Fast, J. D., Gaffney, J. S., Guzman, F., Hubbe, J. M., Lee, J. T., Malone, E. L., Marley, N. A., McNair, L. A., Neff, W., Ortiz, E., Petty, R., Ruiz, M., Shaw, W. J., Sosa, G., Vega, E., Watson, J. G., Whiteman, C. P., and Zhong, S.: Particulate air pollution in Mexico City: A collaborative research project, J. Air Waste Manage., 49, 1221-1229, 1999.

Englert, N.: Fine particles and human health - a review of epidemiological studies, Toxicol. Lett., 149, 235-242, 2004.

30 Fountoukis, C. and Nenes, A.: ISORROPIA-II: a computational efficient thermodynamic equilibrium model for $\mathrm{K}^{+}-\mathrm{Ca}^{2+}-\mathrm{Mg}^{2+}-\mathrm{NH}_{4}^{+}-\mathrm{Na}^{+}-\mathrm{SO}_{4}^{2-}-\mathrm{NO}_{3}^{-}-\mathrm{H}_{2} \mathrm{O}$ aerosols, Atmos. Chem. Phys., 7, 1893-1939, 2007,

http://www.atmos-chem-phys.net/7/1893/2007/.

Thermodynamic partitioning of inorganics in downtown Mexico

M. Moya et al.

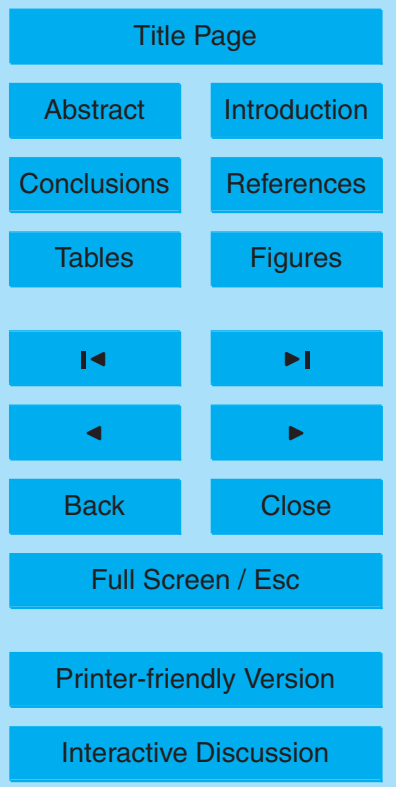


Fountoukis, C., Nenes, A., Sullivan, A., Weber, R., VanReken, T., Fisher, M., Matias, E. Moya, M., Farmer, D., and Cohen, R.: Thermodynamic Characterization of Mexico City Aerosol during MILAGRO 2006, Atmos. Chem. Phys., 7, 9203-9233, 2007,

http://www.atmos-chem-phys.net/7/9203/2007/.

5 Grutter, M., Flores, E., Basaldud, R., and Ruiz-Suarez, L. G.: Open-path FTIR spectroscopic studies of the trace gases over Mexico City. Atmos. Oceanic Opt., 16, 232-236, 2003.

$\mathrm{Ha}, \mathrm{Z}$. and Chan, C.: The water activities of $\mathrm{MgCl}_{2}, \mathrm{Mg}\left(\mathrm{NO}_{3}\right)_{2}, \mathrm{MgSO}_{4}$, and their mixtures, Aerosol Sci. Technol., 31, 154-169, 1999.

Hearing, S. and Cass, G.: The magnitude of bias in the measurement of PM2.5 arising from volatilization of particulate nitrate from Teflon filters. J. Air Waste Manage., 49, 725-733, 1999.

INEGI, http://www.demographia.com/db-mxcward.htm, 2000.

Jacobson, M., Tabazadeh, A., and Turco, R.: Simulating equilibrium within aerosols and nonequilibrium between gases and aerosols, J. Geophys. Res., 101, 9079-9091, 1996.

Jacobson, M. Z.: Studying the effects of calcium and magnesium on size-distributed nitrate and ammonium with EQUISOLV II, Atmos. Environ., 33, 3635-3649, 1999.

Kelly, J. T. and Wexler, A. S.: Water uptake by aerosols: Water activity in supersaturated potassium and deliquescence as a function of temperature, Atmos. Environ., 40, 4450-4468, 2006.

20 Kim, Y. P., Seinfeld, J. H., and Saxena, P.: Atmospheric gas-aerosol equilibrium I. Thermodynamic model, Aerosol Sci. Technol., 19, 157-181, 1993a.

Kim, Y. P., Seinfeld, J. H., and Saxena, P.: Atmospheric gas-aerosol equilibrium II. Analysis of common approximations and activity coefficients calculation methods, Aerosol Sci. Technol., 19, 182-198, 1993b.

Kim, Y. P., Seinfeld, J. H., and Saxena, P.: Atmospheric gas-aerosol equilibrium III. Thermodynamics of crustal elements $\mathrm{Ca}^{2+}, \mathrm{K}^{+}$and $\mathrm{Mg}^{2+}$, Aerosol Sci. Technol., 22, 93-110, 1995.

Kline, J., Huebert, B., Howell, S., Blomquist, B., Zhuan, J., Bertram, T., and Carrillo, J.: Aerosol composition and size versus altitude measured from the C-130 during ACE-Asia, J. Geophys. Res., 109, D19S08, doi:10.1029/2004JD004540, 2004.

30 Kusik, C. L. and Meissner, H. P.: Electrolyte activity coefficients in inorganic processing, AIChE Symposium Series, 173, 14-20, 1978.

Lee, Y. M., Weber, R., Ma, Y., Orsini, D., Maxwell-Meier, K., Blake, D., Meinardi, S., Sachse, G., Harward, C., Chen, T. Y., Thornton, D., Tu, F. H., and Bandy, A.: Airborne measurement

Thermodynamic partitioning of inorganics in downtown Mexico

M. Moya et al.

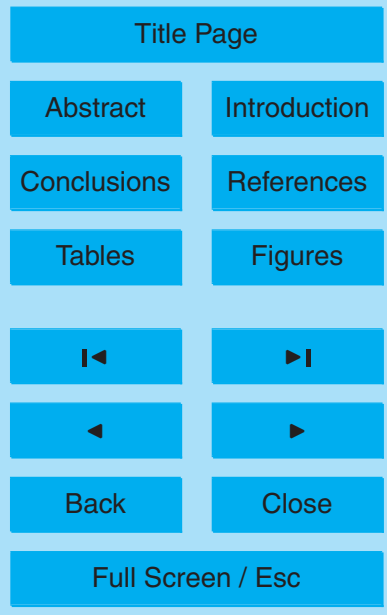

Printer-friendly Version

Interactive Discussion 
of inorganic ionic components of fine aerosol particles using the particle-into-liquid sampler coupled to ion chromatography technique during ACE-Asia and TRACE-P., J. Geophys. Res., 108(D23), doi:10.1029/2002JD003265, 2003.

Lurmann, F. W., Wexler, A. S., Pandis, S.N., Musarra, S., Kumar, N., and Seinfeld, J. H.: Modeling urban and regional aerosols. II. Application to California's South Coast Air Basin, Atmos. Environ., 31, 2695-2715, 1997.

Matías, E.: Evaluación de modelos termodinámicos en la predicción de partículas atmosféricas finas (componente inorgánica) a condiciones del centro histórico de la Ciudad de México, durante febrero-marzo, 2005, Master's Thesis, UNAM-Mexico, 2007.

10 Maxwell-Meier, Weber, R., Song, C., Orsini, D., Ma, Y., Carmichael, G. R., and Streets, D. G.: Inorganic composition of fine particles in mixed mineral dust-pollution plumes observed from airborne measurements during ACE-Asia, J. Geophys. Res., 109, D19S07, doi:10.1029/2003JD004464, 2004.

Meng, Z. Y., Seinfeld, J. H., Saxena, P., and Kim, Y. P.: Atmospheric Gas-Aerosol Equilibrium 15 IV. Thermodynamics of Carbonates, Aerosol Sci. Technol., 23, 131-154, 1995.

Metzger, S., Dentener, F., Pandis, S. N., and Lelieveld, J.: Gas/aerosol partitioning: 1. A computationally efficient model, J. Geophys. Res., 107(D16), 4312, doi:10.1029/2001JD001102, 2002.

Molina, M. and Molina, L. T.: Air Quality in the México Megacity: An integrated assessment.

$20 \quad$ Kluwer Academic Publishers, Dordrecht, 2002.

Moya, M. Ansari, A. S., and Pandis, S. N.: Partitioning of nitrate and ammonium between the gas and particulate phases during the 1997 IMADA AVER study in Mexico City, Atmos. Environ., 35, 1791-1804, 2001.

Moya, M., Pandis, S. N., and Jacobson, M. Z.: Is the size distribution of urban aerosols deter25 mined by thermodynamic equilibrium? An application to Southern California, Atmos. Environ., 36, 2349-2365, 2002a.

Moya, M., Avalos-González, E., Baumgardner, D., and Raga, G. B.: Predicting sizedifferentiated inorganic species for México City conditions with SELIQUID, Proceedings of the 2002 American Association for Aerosol Research Conference, Charlotte, NC, USA, 30 2002b.

Moya, M., Grutter, M., and Báez, A.: Diurnal variability of size differentiated inorganic aerosols and their gas-phase precursors during January and February of 2003 near downtown Mexico City, Atmos. Environ., 38, 5651-5661, 2004.

\section{Thermodynamic partitioning of inorganics in downtown Mexico}

M. Moya et al.

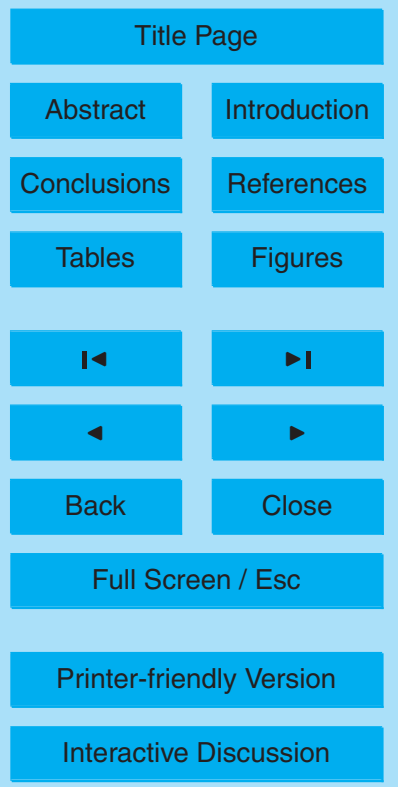


Moya, M. and Huey, G.: Some aspects of fine inorganic aerosols $\left(\mathrm{PM}_{1}, \mathrm{PM}_{2.5}\right)$ and precursors in the metropolitan area of Mexico City during the winters of 2003, 2005 and 2006 (MIRAGE-MILAGRO field campaign). Proceedings of the 2007 European Aerosol Conference, Salzburg, Austria, 2007.

5 Nenes, A., Pilinis, C., and Pandis, S. N.: ISORROPIA: a new thermodynamic equilibrium model for multiphase multicomponent inorganic aerosols, Aquatic Geochem., 4, 123-152, 1998.

Nikasinovich, L., Just, J., Sahraoui, F., Seta, N., Grimfeld, A., and Momas, I.: Nasal inflammation and personal exposure to fine particles PM2.5 in asmathic children. American Academy of Allergy, Asthma and Immunology, doi:10.1016/j.jaci.2006.03.023, 2006.

10 Peters, A.: Particulate matter and heart disease: Evidence from epidemiological studies, Toxicol. Appl. Pharm., 207, S477-S482, 2005.

Peters, A., Veronesi, B., Calderón-Garcidueñas, L., Gehr, P., Chi Che, L., Geiser, M., Reed, W., Rothen-Rutishauser, B., Schurch, S., Shulz, H.: Translocation and potential neurological effects of fine and ultrafine particles. A critical updated, Part. Fibre Toxicol., 3(13), doi:10.1186/1743-8977-3-13, 2006.

Pilinis, C. and Seinfeld, J. H.: Continued development of a general equilibrium model for inorganic multicomponent atmospheric aerosols, Atmos. Environ., 21, 2453-2466, 1987.

Rothman, L. S., Rinsland, C. P., Goldman, A., Massie, S. T., Edwards, D. P., Flaud, J. M., et al.: The HITRAN molecular spectroscopic database, J. Quant. Spectros. RA. 60, 665-710, 1998.

Seinfeld, J. H. and Pandis, S. N.: Atmospheric Chemistry and Physics. From air pollution to climate change. Wiley Interscience. New York. USA, 1998.

Schaap, M., Spindler, G., Schulz, M., Acker, K., Maenhaut, W., Berner, A., Wieprecht, W., Streit, N., Müller, K., Brüggemann, E., Chi, X., Putaud, J. P., Hitzenberger, R., Puxbaum, H., Baltensperger, U., and Brink, H.: Artefacts in the sampling of nitrate studied in the "INTERCOMP" campaigns of EUROTRAC-AEROSOL, Atmos. Environ, 38, 6487-6496, 2004.

Shaw, R., Stevens, R. K., et al.: Measurements of atmospheric nitrate and nitric acid: the denuder difference experiment, Atmos. Environ, 16, 845-853, 1982.

Schulz, H., Harder, V., Ibald-Mulli, A., Khandoga, A., Koenig, W., Krobach, F., Radykewicz, 30 R., Stampfl, A., Thorand, B., and Petters, A.: Cardiovascular effects of fine and ultrafine particles, J. Aerosol Med., 1, 1-22, 2005.

Topping, D. O., McFiggans, G. B., and Coe, H.: A curved multicomponent aerosol hygroscopicity model framework: Part 1 - Inorganic compounds, Atmos. Chem. Phys., 5, 1205-1222,

Thermodynamic partitioning of inorganics in downtown Mexico

M. Moya et al.

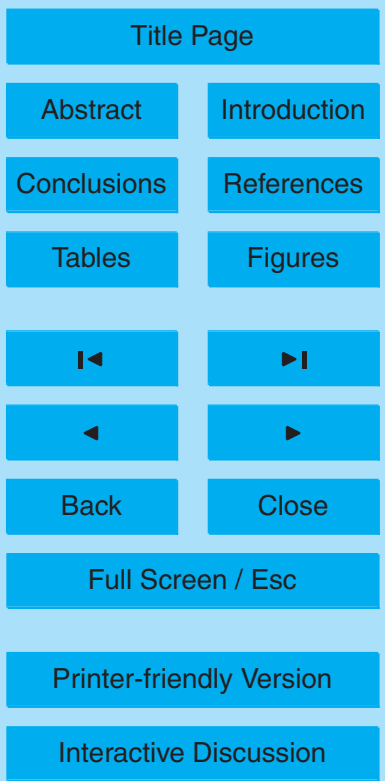


2005,

http://www.atmos-chem-phys.net/5/1205/2005/.

Trebs, I., Metzger, S., Meixner, F. X., Helas, G., Hoffer, A., Rudich, Y., Falkovich, A. H., Moura, M. A. L., da Silva, R. S., Artaxo, P., Slanina, J., and Andreae, M. O.: The $\mathrm{NH}_{4}^{+}-\mathrm{SO}_{4}^{2-}-$ $\mathrm{NO}_{3}^{-}-\mathrm{Cl}^{-}-\mathrm{H}_{2} \mathrm{O}$ aerosol system and its gas phase precursors at a pasture site in the Amazon Basin: How relevant are mineral cations and soluble organic acids?, J. Geophys. Res., 110, D07303, doi: 10.1029/2004JD00547, 2005.

Wexler A. S. and Seinfeld, J. H.: The distribution of ammonium salts among a size and compositional dispersed aerosol, Atmos. Environ., 24A, 1231-1246, 1990.

10 Wexler A. S. and Seinfeld, J. H.: Second-generation inorganic aerosol model, Atmos. Environ., 25, 2731-2748, 1991.

Wexler A. S. and Seinfeld, J. H.: Analysis of aerosol ammonium nitrate: departures from equilibrium during SCAQS, Atmos. Environ., 26A, 579-591, 1992.

Wexler, A. S. and Clegg, S. L.: Atmospheric aerosol models for systems including the ions $\mathrm{H}^{+}, \mathrm{NH}_{4}^{+}, \mathrm{Na}^{+}, \mathrm{SO}_{4}^{2-}, \mathrm{NO}_{3}^{-}, \mathrm{Cl}^{-}, \mathrm{Br}^{-}$and $\mathrm{H}_{2} \mathrm{O}$, J. Geophys. Res., 107, 4207, doi:10.1029/2001JD000451, 2002.

Zaveri, R. A., Easter, R. C., and Peters, L. K.: A computationally efficient Multicomponent Equilibrium Solver for Aerosols (MESA), J. Geophys. Res., 110, D24203, doi:10.1029/2004JD005618, 2005.

\section{Thermodynamic partitioning of inorganics in downtown Mexico}

M. Moya et al.

Title Page

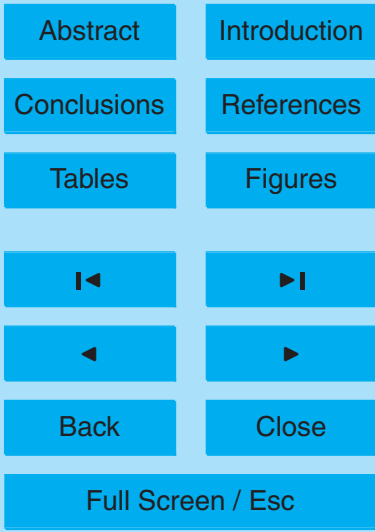

Printer-friendly Version

Interactive Discussion 


\section{ACPD}

7, 11257-11294, 2007

\section{Thermodynamic partitioning of inorganics in \\ downtown Mexico}

Table 1. Observed $\mathrm{PM}_{1}$ concentrations for inorganic species at the Merced site, from 17 February to 4 March, 2005.

M. Moya et al.

\begin{tabular}{lcccc}
\hline Species & $\begin{array}{c}\text { Mean observed } \\
\left(\mu \mathrm{g} \mathrm{m}^{-3}\right)\end{array}$ & $\begin{array}{c}\text { Maximum value } \\
\left(\mu \mathrm{g} \mathrm{m}^{-3}\right)\end{array}$ & $\begin{array}{c}\text { Gas phase } \\
\text { (average value, \%) }\end{array}$ & $\begin{array}{c}\text { Particulate phase } \\
\text { (average value, \%) }\end{array}$ \\
\hline Total Nitrate & 12.60 & 27.10 & $40^{*}$ & 60 \\
Total ammonium & 20.10 & 33.70 & 68 & 32 \\
Sulfate & 12.90 & 23.70 & 0 & 100 \\
Sodium & 0.70 & 1.90 & 0 & 100 \\
Calcium & 0.50 & 1.10 & 0 & 100 \\
Potassium & 1.30 & 2.60 & 0 & 100 \\
Magnesium & 0.10 & 0.50 & 0 & 100 \\
* Denuded $\mathrm{HNO}_{3}$ & & & & \\
\hline
\end{tabular}

Title Page

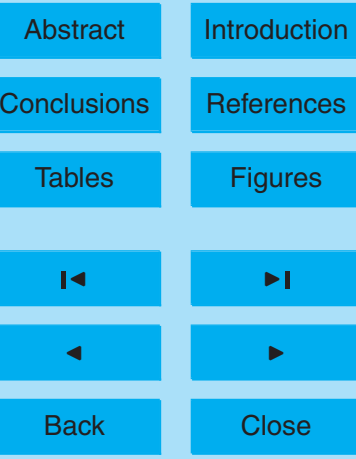

Full Screen / Esc

Printer-friendly Version

Interactive Discussion 


\section{ACPD}

7, 11257-11294, 2007

\section{Thermodynamic partitioning of inorganics in \\ downtown Mexico}

Table 2. Observed $\mathrm{PM}_{2.5}$ concentrations for inorganic species at the Merced site, from 17 February to 4 March 2005.

M. Moya et al.

\begin{tabular}{lcccc}
\hline Species & $\begin{array}{c}\text { Mean observed } \\
\left(\mu \mathrm{g} \mathrm{m}^{-3}\right)\end{array}$ & $\begin{array}{c}\text { Maximum value } \\
\left(\mu \mathrm{g} \mathrm{m}^{-3}\right)\end{array}$ & $\begin{array}{c}\text { Gas phase } \\
\text { (average value, \%) }\end{array}$ & $\begin{array}{c}\text { Particulate phase } \\
\text { (average value, \%) }\end{array}$ \\
\hline Total Nitrate & 16.20 & 40.00 & $30^{*}$ & 70 \\
Total ammonium & 22.10 & 36.80 & 60 & 40 \\
Sulfate & 18.90 & 30.11 & 0 & 100 \\
Sodium & 1.00 & 3.50 & 0 & 100 \\
Calcium & 1.00 & 3.50 & 0 & 100 \\
Potassium & 1.80 & 2.90 & 0 & 100 \\
Magnesium & 0.20 & 0.60 & 0 & 100 \\
${ }^{*}$ Denuded $\mathrm{HNO}_{3}$ & & & & \\
\hline
\end{tabular}

Title Page

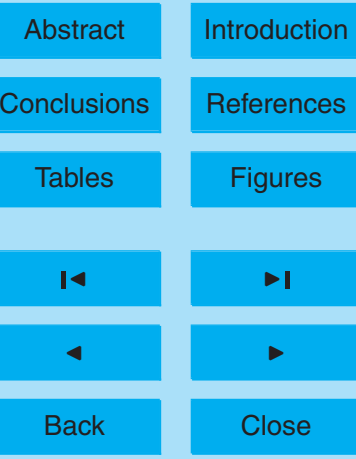

Full Screen / Esc

Printer-friendly Version

Interactive Discussion 


\section{ACPD}

7, 11257-11294, 2007

\section{Thermodynamic partitioning of inorganics in \\ downtown Mexico}

Table 3. SCAPE2 model performance for $\mathrm{PM}_{1}$ ammonium and nitrate by applying deliquescence branch, at the Merced site from 17 February to 4 March 2005.

M. Moya et al.

\begin{tabular}{lcrrrr}
\hline & & \multicolumn{2}{c}{ ammonium } & \multicolumn{2}{c}{ nitrate } \\
\multicolumn{2}{c}{ Sampling period } & gas & particulate & gas & particulate \\
\hline Overall & $\%$ MNB & -1 & 9 & -21 & 13 \\
& $\%$ MNE & 13 & 31 & 82 & 56 \\
06:00-10:00 & $\%$ MNB & -3 & 19 & -95 & 58 \\
& $\%$ MNE & 6 & 47 & 95 & 58 \\
$10: 00-14: 00$ & $\%$ MNB & -11 & 22 & -43 & 35 \\
& $\%$ MNE & 16 & 23 & 47 & 36 \\
$14: 00-18: 00$ & $\%$ MNB & 18 & -22 & 113 & -82 \\
& $\%$ MNE & 18 & 22 & 113 & 82 \\
\hline
\end{tabular}

Title Page

Abstract

Introduction

Conclusions

References

Tables

Figures

14

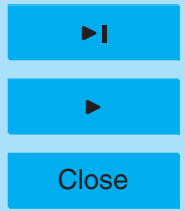

Back

Full Screen / Esc

Printer-friendly Version

Interactive Discussion 


\section{ACPD}

7, 11257-11294, 2007

\section{Thermodynamic partitioning of inorganics in \\ downtown Mexico}

Table 4. SCAPE2 model performance for $\mathrm{PM}_{2.5}$ ammonium and nitrate by applying deliquescence branch, at the Merced site from 17 February to 4 March 2005.

M. Moya et al.

\begin{tabular}{lcrrrr}
\hline & & \multicolumn{2}{c}{ ammonium } & \multicolumn{2}{c}{ nitrate } \\
\multicolumn{2}{c}{ Sampling period } & gas & particulate & gas & particulate \\
\hline Overall & $\%$ MNB & 4 & 6 & 12 & -5 \\
& $\%$ MNE & 15 & 24 & 105 & 44 \\
06:00-10:00 & $\%$ MNB & -3 & 31 & -93 & 34 \\
& $\%$ MNE & 5 & 33 & 93 & 34 \\
$10: 00-14: 00$ & $\%$ MNB & -4 & 6 & 0 & 11 \\
& $\%$ MNE & 14 & 18 & 82 & 30 \\
$14: 00-18: 00$ & $\%$ MNB & 27 & -24 & 156 & -78 \\
& $\%$ MNE & 27 & 24 & 156 & 78 \\
\hline
\end{tabular}

Title Page

Abstract

Introduction

Conclusions

References

Tables

Figures

14

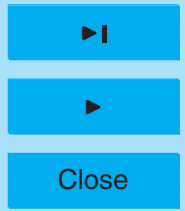

Back

Full Screen / Esc

Printer-friendly Version

Interactive Discussion 


\section{ACPD}

7, 11257-11294, 2007

\section{Thermodynamic partitioning of inorganics in \\ downtown Mexico}

Table 5. ISORROPIA-II model performance for $\mathrm{PM}_{1}$ ammonium and nitrate by applying deliquescence branch, at the Merced site from 17 February to 4 March 2005.

M. Moya et al.

\begin{tabular}{lcrrrr}
\hline & & \multicolumn{2}{c}{ ammonium } & \multicolumn{2}{c}{ nitrate } \\
\multicolumn{2}{c}{ Sampling period } & gas & particulate & gas & particulate \\
\hline Overall & $\%$ MNB & -1 & 4 & -18 & 13 \\
& $\%$ MNE & 14 & 30 & 94 & 66 \\
06:00-10:00 & $\%$ MNB & -3 & 12 & -97 & 61 \\
& $\%$ MNE & 6 & 41 & 97 & 61 \\
$10: 00-14: 00$ & $\%$ MNB & -14 & 19 & -55 & 45 \\
& $\%$ MNE & 17 & 21 & 55 & 45 \\
$14: 00-18: 00$ & $\%$ MNB & 19 & -28 & 145 & -100 \\
& $\%$ MNE & 19 & 28 & 145 & 100 \\
\hline
\end{tabular}

Title Page

Abstract

Introduction

Conclusions

References

Tables

Figures

14

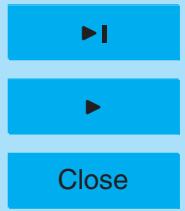

Back

Full Screen / Esc

Printer-friendly Version

Interactive Discussion 


\section{ACPD}

7, 11257-11294, 2007

\section{Thermodynamic partitioning of inorganics in \\ downtown Mexico}

Table 6. ISORROPIA-II model performance for $\mathrm{PM}_{2.5}$ ammonium and nitrate by applying deliquescence branch, at the Merced site from 17 February to 4 March 2005.

M. Moya et al.

\begin{tabular}{lcrrrr}
\hline & & \multicolumn{2}{c}{ ammonium } & \multicolumn{2}{c}{ nitrate } \\
\multicolumn{2}{c}{ Sampling period } & gas & particulate & gas & particulate \\
\hline Overall & $\%$ MNB & 6 & -1 & 32 & -11 \\
& $\%$ MNE & 15 & 24 & 124 & 52 \\
06:00-10:00 & $\%$ MNB & -3 & 23 & -93 & 36 \\
& $\%$ MNE & 5 & 28 & 93 & 36 \\
$10: 00-14: 00$ & $\%$ MNB & -3 & -1 & 15 & 9 \\
& $\%$ MNE & 15 & 17 & 95 & 34 \\
$14: 00-18: 00$ & $\%$ MNB & 29 & -30 & 208 & -100 \\
& $\%$ MNE & 29 & -30 & 208 & -100 \\
\hline
\end{tabular}

Title Page

Abstract

Introduction

Conclusions

References

Tables

Figures

14

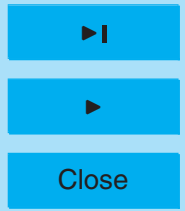

Back

Full Screen / Esc

Printer-friendly Version

Interactive Discussion 


\section{ACPD}

7, 11257-11294, 2007

\section{Thermodynamic partitioning of inorganics in \\ downtown Mexico}

Table 7. SCAPE2 model performance for $\mathrm{PM}_{1}$ ammonium and nitrate by applying efflorescence branch, at the Merced site from 17 February to 4 March 2005.

M. Moya et al.

\begin{tabular}{lcrrrr}
\hline & & \multicolumn{2}{c}{ ammonium } & \multicolumn{2}{c}{ nitrate } \\
\multicolumn{2}{c}{ Sampling period } & gas & particulate & gas & particulate \\
\hline Overall & $\%$ MNB & 7 & 0 & 1 & 2 \\
& $\%$ MNE & 15 & 31 & 83 & 51 \\
06:00-10:00 & $\%$ MNB & -3 & 18 & -95 & 58 \\
& $\%$ MNE & 6 & 46 & 95 & 58 \\
$10: 00-14: 00$ & $\%$ MNB & 11 & -5 & 42 & -10 \\
& $\%$ MNE & 22 & 24 & 74 & 37 \\
$14: 00-18: 00$ & $\%$ MNB & 16 & -20 & 78 & -61 \\
& $\%$ MNE & 16 & 20 & 78 & 61 \\
\hline
\end{tabular}

Title Page

Abstract

Introduction

Conclusions

References

Tables

Figures

14

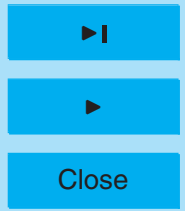

Back

Full Screen / Esc

Printer-friendly Version

Interactive Discussion 


\section{ACPD}

7, 11257-11294, 2007

\section{Thermodynamic partitioning of inorganics in \\ downtown Mexico}

Table 8. SCAPE2 model performance for $\mathrm{PM}_{2.5}$ ammonium and nitrate by applying efflorescence branch, at the Merced site from 17 February to 4 March 2005.

M. Moya et al.

\begin{tabular}{lcrrrr}
\hline & & \multicolumn{2}{c}{ ammonium } & \multicolumn{2}{c}{ nitrate } \\
\multicolumn{2}{c}{ Sampling period } & gas & particulate & gas & particulate \\
\hline Overall & $\%$ MNB & 13 & -5 & 36 & -15 \\
& $\%$ MNE & 18 & 23 & 101 & 42 \\
06:00-10:00 & $\%$ MNB & -3 & 21 & -83 & 32 \\
& $\%$ MNE & 4 & 24 & 83 & 32 \\
$10: 00-14: 00$ & $\%$ MNB & 16 & -15 & 73 & -23 \\
& $\%$ MNE & 24 & 23 & 103 & 38 \\
$14: 00-18: 00$ & $\%$ MNB & 26 & -22 & 119 & -60 \\
& $\%$ MNE & 26 & 22 & 119 & 60 \\
\hline
\end{tabular}

Title Page

Abstract

Introduction

Conclusions

References

Tables

Figures

14

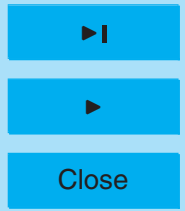

Back

Full Screen / Esc

Printer-friendly Version

Interactive Discussion 


\section{ACPD}

7, 11257-11294, 2007

\section{Thermodynamic partitioning of inorganics in \\ downtown Mexico}

Table 9. ISORROPIA-II model performance for $\mathrm{PM}_{1}$ ammonium and nitrate by applying efflorescence branch, at the Merced site from 17 February to 4 March, 2005.

M. Moya et al.

\begin{tabular}{lcrrrr}
\hline & & \multicolumn{2}{c}{ ammonium } & \multicolumn{2}{c}{ nitrate } \\
\multicolumn{2}{c}{ Sampling period } & gas & particulate & gas & particulate \\
\hline Overall & $\%$ MNB & 3 & -1 & -18 & 14 \\
& $\%$ MNE & 12 & 28 & 72 & 47 \\
06:00-10:00 & $\%$ MNB & -3 & 13 & -97 & 61 \\
& $\%$ MNE & 6 & 41 & 97 & 61 \\
$10: 00-14: 00$ & $\%$ MNB & 0 & 2 & 3 & 13 \\
& $\%$ MNE & 16 & 19 & 52 & 30 \\
$14: 00-18: 00$ & $\%$ MNB & 16 & -23 & 63 & -50 \\
& $\%$ MNE & 16 & 23 & 63 & 50 \\
\hline
\end{tabular}

Title Page

Abstract

Introduction

Conclusions

References

Tables

Figures

14

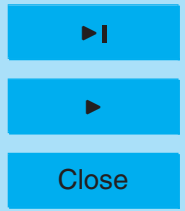

Back

Full Screen / Esc

Printer-friendly Version

Interactive Discussion 


\section{ACPD}

7, 11257-11294, 2007

\section{Thermodynamic partitioning of inorganics in \\ downtown Mexico}

Table 10. ISORROPIA-II model performance for $\mathrm{PM}_{2.5}$ ammonium and nitrate by applying efflorescence branch, at the Merced site from 17 February to 4 March 2005.

M. Moya et al.

\begin{tabular}{lcrrrr}
\hline & & \multicolumn{2}{c}{ ammonium } & \multicolumn{2}{c}{ nitrate } \\
\multicolumn{2}{c}{ Sampling period } & gas & particulate & gas & particulate \\
\hline Overall & $\%$ MNB & 7 & -4 & 6 & -1 \\
& $\%$ MNE & 15 & 22 & 86 & 36 \\
06:00-10:00 & $\%$ MNB & -3 & 20 & -92 & 36 \\
& $\%$ MNE & 5 & 24 & 92 & 36 \\
$10: 00-14: 00$ & $\%$ MNB & 5 & -8 & 28 & -2 \\
& $\%$ MNE & 16 & 17 & 82 & 31 \\
$14: 00-18: 00$ & $\%$ MNB & 24 & -25 & 87 & -45 \\
& $\%$ MNE & 24 & 25 & 87 & 45 \\
\hline
\end{tabular}

Title Page

Abstract

Introduction

Conclusions

References

Tables

Figures

14

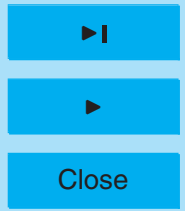

Back

Full Screen / Esc

Printer-friendly Version

Interactive Discussion 


\section{ACPD}

7, 11257-11294, 2007

\section{Thermodynamic partitioning of inorganics in downtown Mexico}

M. Moya et al.

Table 11. Four-hour particulate nitrate measurements stratified by sampling period.

\begin{tabular}{lll}
\hline \multicolumn{3}{c}{ Particulate nitrate $\left(\mu \mathrm{g} \mathrm{m}^{-3}\right)$} \\
\hline Sampling Period & $\mathrm{PM}_{1}$ & $\mathrm{PM}_{2.5}$ \\
\hline 06:00-10:00 & $6.2 \pm 1.8$ & $10.3 \pm 4.4$ \\
10:00-14:00 & $13.0 \pm 4.4$ & $17.5 \pm 8.8$ \\
14:00-18:00 & $1.7 \pm 0.95$ & $2.3 \pm 0.96$ \\
\hline
\end{tabular}

Title Page 


\section{ACPD}

7, 11257-11294, 2007

\section{Thermodynamic partitioning of inorganics in downtown Mexico}

M. Moya et al.

Table 12. Sulfate-to-nitrate molar ratios stratified by sampling period observed at the Merced site.

\begin{tabular}{|c|c|c|}
\hline \multicolumn{3}{|c|}{ Sulfate/Nitrate Molar Ratio } \\
\hline Sampling Period & $\mathrm{PM}_{1}$ & $\mathrm{PM}_{2.5}$ \\
\hline 06:00-10:00 & 0.8 & 0.9 \\
\hline $10: 00-14: 00$ & 0.4 & 0.6 \\
\hline $14: 00-18: 00$ & 3.4 & 1.6 \\
\hline
\end{tabular}

Title Page

Abstract Introduction

Conclusions References

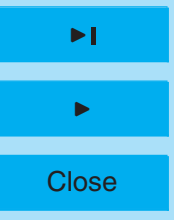

Back

Full Screen / Esc

Printer-friendly Version

Interactive Discussion 


\section{ACPD}

7, 11257-11294, 2007

\section{Thermodynamic partitioning of inorganics in \\ downtown Mexico}

Table 13. ISORROPIA-II without crustals model performance for $\mathrm{PM}_{1}$ ammonium and nitrate by applying efflorescence branch, at the Merced site from 17 February to 4 March, 2005.

M. Moya et al.

\begin{tabular}{lcrrrr}
\hline & & \multicolumn{2}{c}{ ammonium } & \multicolumn{2}{c}{ nitrate } \\
\multicolumn{2}{c}{ Sampling period } & gas & particulate & gas & particulate \\
\hline Overall & $\%$ MNB & -7 & 23 & -13 & 17 \\
& $\%$ MNE & 10 & 26 & 67 & 46 \\
06:00-10:00 & $\%$ MNB & -14 & 47 & -91 & 72 \\
& $\%$ MNE & 14 & 47 & 91 & 72 \\
10:00-14:00 & $\%$ MNB & -9 & 22 & -2 & 15 \\
& $\%$ MNE & 9 & 23 & 52 & 27 \\
14:00-18:00 & $\%$ MNB & 5 & -6 & 62 & -45 \\
& $\%$ MNE & 6 & 7 & 62 & 45 \\
\hline
\end{tabular}

Title Page

Abstract

Introduction

Conclusions

References

Tables

Figures

14

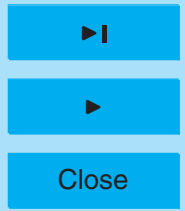

Back

Full Screen / Esc

Printer-friendly Version

Interactive Discussion 


\section{ACPD}

7, 11257-11294, 2007

\section{Thermodynamic partitioning of inorganics in \\ downtown Mexico}

Table 14. ISORROPIA-II without crustals model performance for $\mathrm{PM}_{2.5}$ ammonium and nitrate by applying efflorescence branch, at the Merced site from 17 February to 4 March 2005.

M. Moya et al.

\begin{tabular}{lcrrrr}
\hline & & \multicolumn{2}{c}{ ammonium } & \multicolumn{2}{c}{ nitrate } \\
\multicolumn{2}{c}{ Sampling period } & gas & particulate & gas & particulate \\
\hline Overall & $\%$ MNB & -8 & 19 & 8 & -2 \\
& $\%$ MNE & 14 & 26 & 86 & 36 \\
06:00-10:00 & $\%$ MNB & -11 & 49 & -93 & 36 \\
& $\%$ MNE & 11 & 49 & 93 & 36 \\
10:00-14:00 & $\%$ MNB & -13 & 9 & 32 & -4 \\
& $\%$ MNE & 19 & 19 & 78 & 30 \\
14:00-18:00 & $\%$ MNB & 4 & 0 & 90 & -46 \\
& $\%$ MNE & 8 & 10 & 90 & 46 \\
\hline
\end{tabular}

Title Page

Abstract

Introduction

Conclusions

References

Tables

Figures

14

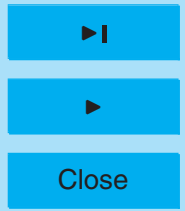

Back

Full Screen / Esc

Printer-friendly Version

Interactive Discussion 
Table 15. Concentration of anions and cations (in neq $\mathrm{m}^{-3}$ ) for the current dataset $\left(\mathrm{PM}_{1}, \mathrm{PM}_{2.5}\right)$ stratified by sampling period.

\begin{tabular}{lcccccccc}
\hline & $\mathrm{Cl}^{-}$ & $\mathrm{NO}_{3}^{-}$ & $\mathrm{SO}_{4}^{2-}$ & $\begin{array}{l}\mathrm{Na}^{+} \\
\left(\mathrm{neq} \mathrm{m}^{-3}\right)\end{array}$ & $\mathrm{NH}_{4}^{+}$ & $\mathrm{K}^{+}$ & $\mathrm{Ca}^{2+}$ & $\mathrm{Mg}^{2+}$ \\
\hline 06:00-10:00 h LST & & & & & & & & \\
PM1.0 & 22.8 & 96.3 & 239.2 & 28.1 & 255.1 & 28.6 & 21.2 & 9.0 \\
PM2.5 & 30.4 & 166.2 & 385.1 & 40.0 & 443.8 & 50.8 & 72.5 & 19.0 \\
& & & & & & & & \\
10:00-14:00 h LST & & & & & & & & \\
PM1.0 & 7.5 & 209.9 & 255.5 & 26.3 & 381.7 & 30.7 & 28.5 & 7.5 \\
PM2.5 & 8.4 & 283.0 & 363.7 & 50.1 & 489.2 & 41.7 & 42.3 & 14.0 \\
& & & & & & & & \\
14:00-18:00h LST & & & & & & & & \\
PM1.0 & 3.9 & 27.5 & 307.5 & 33.5 & 268.5 & 33.3 & 24.1 & 9.7 \\
PM2.5 & 4.0 & 37.4 & 416.1 & 48.1 & 380.7 & 42.1 & 38.4 & 6.8 \\
\hline
\end{tabular}

\section{ACPD}

7, 11257-11294, 2007

Thermodynamic partitioning of inorganics in downtown Mexico

M. Moya et al.

Title Page

Abstract

Introduction

Conclusions

References

Tables

Figures

14

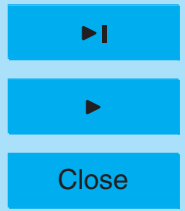

Back

Close

Full Screen / Esc

Printer-friendly Version

Interactive Discussion 


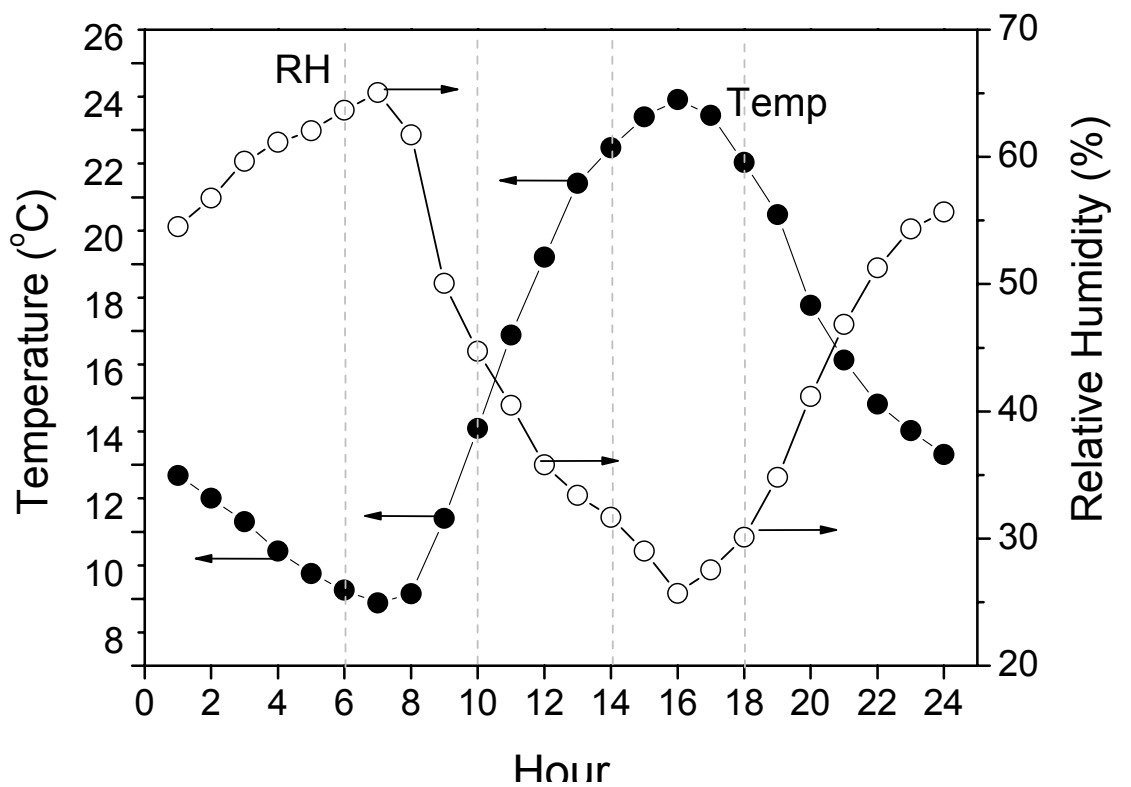

Fig. 1. Average temperature and $\mathrm{RH}$ profile over the period 17-23 February 2005 at the Merced site.
ACPD

7, 11257-11294, 2007

Thermodynamic partitioning of inorganics in downtown Mexico

M. Moya et al.

Title Page

Abstract

Introduction

Conclusions

References

Tables

Figures

14

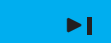

$<$

Back

Full Screen / Esc

Printer-friendly Version

Interactive Discussion 


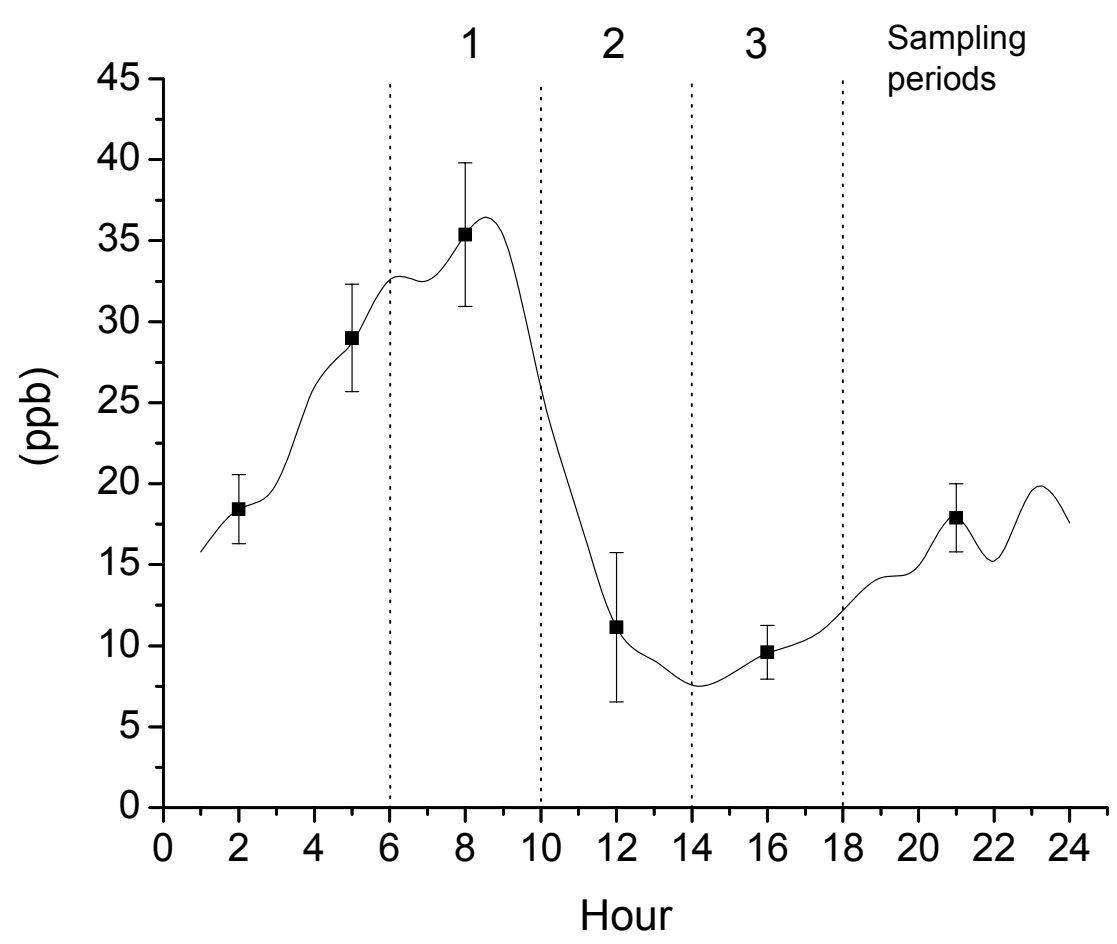

Fig. 2. Ammonia $\left(\mathrm{NH}_{3}\right)$ diurnal profile in parts-per-billion (ppb) from the open-path FTIR measurements for the entire period of study at the MER site. Sampling periods for the filter-based measurements are marked with the vertical lines.

\section{ACPD}

7, 11257-11294, 2007

\section{Thermodynamic partitioning of \\ inorganics in \\ downtown Mexico}

M. Moya et al.

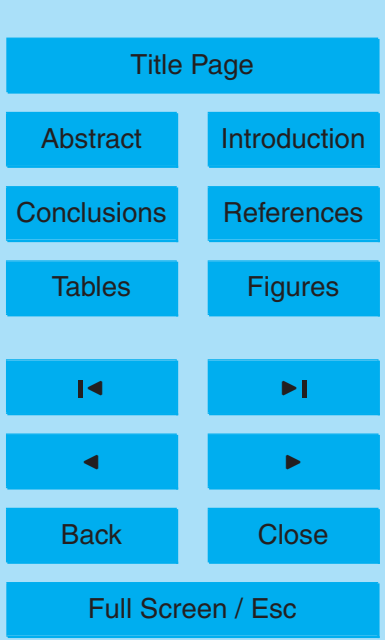

Printer-friendly Version

Interactive Discussion 


\section{ACPD}

7, 11257-11294, 2007

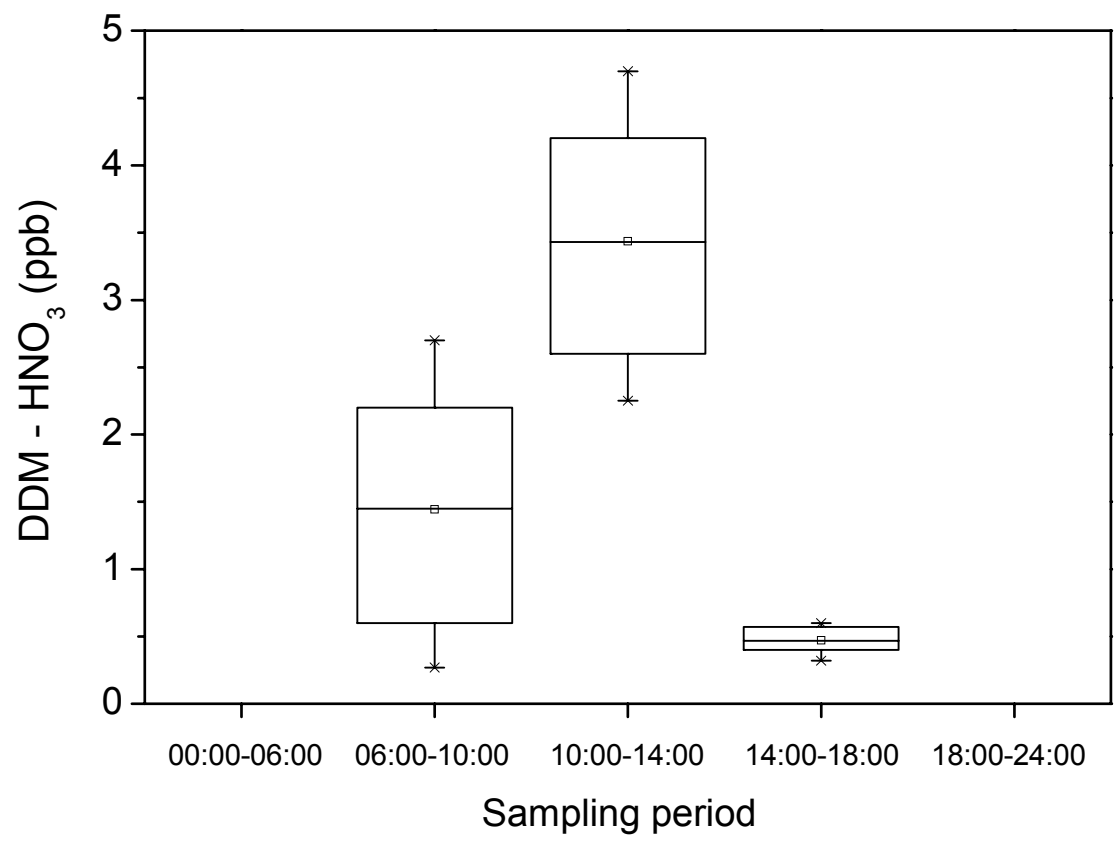

\section{Thermodynamic partitioning of inorganics in downtown Mexico}

M. Moya et al.

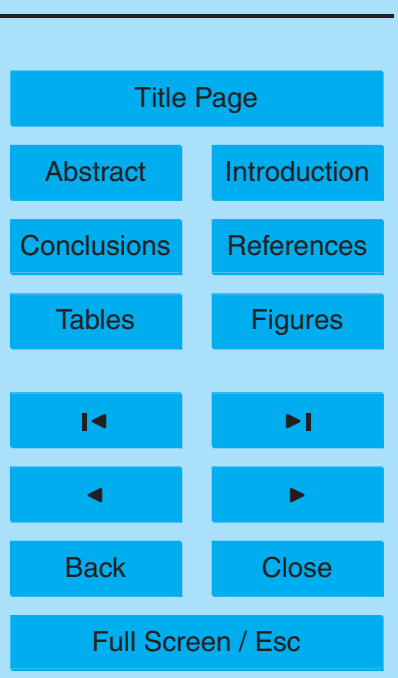

Fig. 3. Nitric acid averages obtained by Denuded Difference Method (DDM- $\left.\mathrm{HNO}_{3}\right)$ during the period 17 February-4 March 2005 at the Merced site. No measurements were available for 00:00-06:00 h, 18:00-24:00 h LST. 

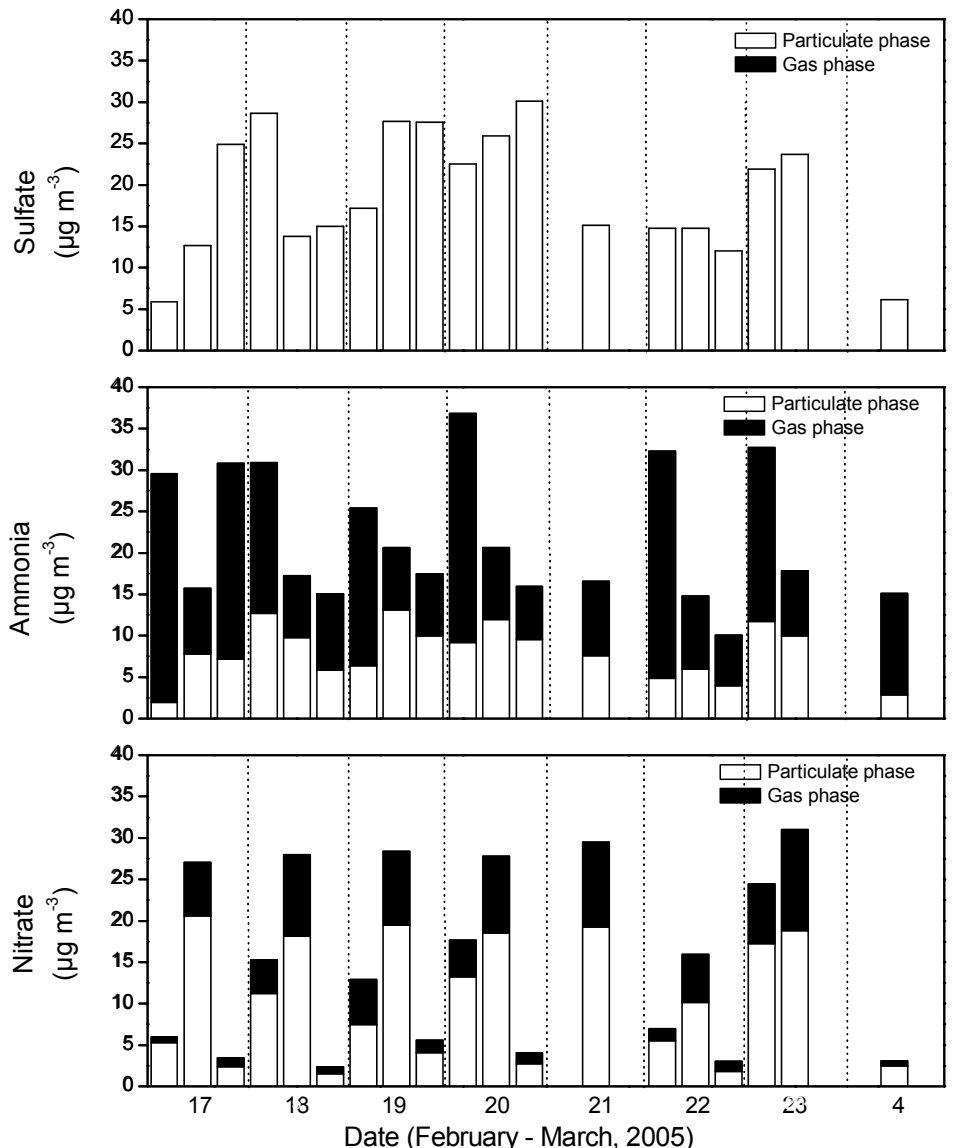

Fig. 4. $\mathrm{PM}_{25}$ total sulfate, ammonia and nitrate during the period 17 February-4 March, 2005. Every day, marked with dotted lines, consist of three sampling periods. The blanks are meaning unavailable data.
ACPD

7, 11257-11294, 2007

Thermodynamic partitioning of

inorganics in downtown Mexico

M. Moya et al.

Title Page
Abstract

Conclusions

Tables

14

4

Back
Introduction

References

Figures

$\rightarrow$

Close
Full Screen / Esc

Printer-friendly Version

Interactive Discussion 